\title{
Origins of Biases in CMIP5 Models Simulating Northwest Pacific Summertime Atmospheric Circulation Anomalies during the Decaying Phase of ENSO 0
}

\author{
Weichen TAO, ${ }^{\mathrm{a}}$ GANG HuAng,,${ }^{\mathrm{a}, \mathrm{b}, \mathrm{c}, \mathrm{d}}$ Renguang Wu, ${ }^{\mathrm{a}, \mathrm{e}}$ KAIMING Hu, ${ }^{\mathrm{a}, \mathrm{c}, \mathrm{e}}$ \\ Pengfei WANG, ${ }^{\mathrm{a}, \mathrm{e}}$ AND Hainan GONG ${ }^{\mathrm{e}}$ \\ a State Key Laboratory of Numerical Modeling for Atmospheric Sciences and Geophysical Fluid Dynamics, \\ Institute of Atmospheric Physics, Chinese Academy of Sciences, Beijing, China \\ ${ }^{\mathrm{b}}$ Laboratory for Regional Oceanography and Numerical Modeling, Qingdao National Laboratory for Marine \\ Science and Technology, Qingdao, China \\ ${ }^{\mathrm{c}}$ Joint Center for Global Change Studies, Beijing, China \\ ${ }^{\mathrm{d}}$ University of Chinese Academy of Sciences, Beijing, China \\ ${ }^{\mathrm{e}}$ Center for Monsoon System Research, Institute of Atmospheric Physics, Chinese Academy of
}

Sciences, Beijing, China

(Manuscript received 3 May 2017, in final form 11 March 2018)

\begin{abstract}
The present study documents the biases of summertime northwest Pacific (NWP) atmospheric circulation anomalies during the decaying phase of ENSO and investigates their plausible reasons in 32 models from phase 5 of the Coupled Model Intercomparison Project. Based on an intermodel empirical orthogonal function (EOF) analysis of El Niño-Southern Oscillation (ENSO)-related 850-hPa wind anomalies, the dominant modes of biases are extracted. The first EOF mode, explaining $21.3 \%$ of total intermodel variance, is characterized by a cyclone over the NWP, indicating a weaker NWP anticyclone. The cyclone appears to be a Rossby wave response to unrealistic equatorial western Pacific (WP) sea surface temperature (SST) anomalies related to excessive equatorial Pacific cold tongue in the models. On one hand, the cold SST biases increase the mean zonal SST gradient, which further intensifies warm zonal advection, favoring the development and persistence of equatorial WP SST anomalies. On the other hand, they reduce the anomalous convection caused by ENSO-related warming, and the resultant increase in downward shortwave radiation contributes to the SST anomalies there. The second EOF mode, explaining $18.6 \%$ of total intermodel variance, features an anticyclone over the NWP with location shifted northward. The related SST anomalies in the Indo-Pacific sector show a tripole structure, with warming in the tropical Indian Ocean and equatorial central and eastern Pacific and cooling in the NWP. The Indo-Pacific SST anomalies are highly controlled by ENSO amplitude, which is determined by the intensity of subtropical cells via the adjustment of meridional and vertical advection in the models.
\end{abstract}

\section{Introduction}

Boreal summer is the major rainy season in East Asia, and the East Asian summer monsoon (EASM) plays a crucial role in this highly populated region. The prominent mode of interannual variability of the EASM is characterized by an anomalous lower-tropospheric anticyclone

Supplemental information related to this paper is available at the Journals Online website: https://doi.org/10.1175/JCLI-D-170289.s1.

Corresponding author: Gang Huang, hg@mail.iap.ac.cn over the northwest Pacific (NWP) or the NWP anticyclone (NWPAC) (Chang et al. 2000; Wang et al. 2008). The NWPAC develops rapidly in late fall of the year when El Niño matures (Zhang et al. 1996; Wang et al. 2000) and persists into the following summer (Wu et al. 2003; Yang et al. 2007; Wu et al. 2009; Xie et al. 2009). During El Niño mature winter and the following spring, the lower-level southerly wind anomalies along the western flank of NWPAC weaken the East Asian winter monsoon, leading to warmer and wetter climate over the southern part of East Asia (Li 1990; Chen et al. 2000; Zhang and Sumi 2002; Huang et al. 2012; Wang and Chen 2014; Zhang et al. 2016). During El Niño decaying summer, the NWPAC 
strengthens the moisture transport from the tropical western Pacific (WP) to subtropical East Asia, increasing the mei-yu-baiu-changma rainfall over East Asia (Wu et al. 2003; Wu et al. 2009; Hu et al. 2017; Tao et al. 2017). Furthermore, the reduced rainfall and downward vertical motion associated with NWPAC lead to above normal surface air temperature over southern China (Hu et al. 2011, 2012). Therefore, the anomalous atmospheric circulation over the NWP plays an important role in bridging teleconnection from El Niño-Southern Oscillation (ENSO) to the East Asian summertime climate (e.g., Zhang et al. 1996; Wang et al. 2000; Yang et al. 2007; Wang et al. 2008; Xie et al. 2009; Chen et al. 2013; Wang and Wu 2012; Chen et al. 2014; Zhao et al. 2015; Zhang et al. 2016; Dong et al. 2018).

Numerous studies have explored mechanisms for the formation and maintenance of the NWPAC at different phases of El Niño (Xie et al. 2016). From El Niño developing fall to decaying spring, the NWPAC develops rapidly (Zhang et al. 1996) and is coupled with local sea surface temperature (SST) (Wang et al. 2000). On one hand, the NWPAC is a Rossby wave response to SST cooling located to its southeast. The northeasterly wind anomalies of NWPAC superimposed on the northeasterly trade winds reinforce initial cold SST anomalies through evaporation, forming a positive thermodynamic feedback between SST and circulation anomalies (Wang et al. 2000; Wang and Zhang 2002). Alternatively, Stuecker et al. (2013) and Stuecker et al. (2015) proposed the so-called combination mode, which emphasizes nonlinear interactions of atmospheric response to slow evolution of equatorial central and eastern Pacific (CEP) SST anomalies with the background annual cycle in the rapid growth of NWPAC.

With the onset of NWP summer monsoon, the positive wind-evaporation-SST feedback turns to a negative feedback as the northeasterly trade winds are replaced by southwesterly winds (Chou et al. 2009), and the local negative SST anomalies gradually decay. In addition, the combination mode effect is weak in the El Niño decaying phase when CEP SST anomalies have dissipated. As a result, the tropical Indian Ocean (TIO) SST anomalies dominate in the maintenance of NWPAC from El Niño decaying spring to summer (e.g., Watanabe and Jin 2002; Yang et al. 2007; Xie et al. 2009; Wu et al. 2010b; Yang et al. 2010; Z. Chen et al. 2016). The TIO warming induces a warm tropospheric Kelvin wave response eastward in atmosphere (Yang et al. 2007; Xie et al. 2009; Yang et al. 2010). The equatorial low pressure in the Kelvin wave drives northeasterly winds, and the resultant lower-level divergence further induces suppressed convection and anomalous anticyclone over the NWP (Xie et al. 2009). The TIO SST anomalies prolong the influence of El Niño on NWPAC like a capacitor (Yang et al. 2007; Xie et al. 2009; Yang et al. 2010). The accompanying NWP cooling in summer makes additional contributions to the NWP anomalous anticyclone (Wu et al. 2010b; Wu et al. 2014a). Recently, Xie and Zhou (2017) illustrated the physical identity of combination mode, which triggers the onset of NWPAC. The NWP cooling and TIO warming then form the Indo-northwestern Pacific Ocean capacitor (IPOC) mode, which amplifies and anchors the NWPAC.

The complex air-sea interactions involved in the evolution of NWPAC pose a challenge for the coupled ocean-atmosphere general circulation models (CGCMs) to simulate the NWPAC realistically. The World Climate Research Programme's (WCRP's) phases 3 and 5 of the Coupled Model Intercomparison Project (CMIP3 and CMIP5) for the IPCC Fourth and Fifth Assessment Reports (AR4 and AR5) (Meehl et al. 2007; Taylor et al. 2012) provide good opportunities for evaluating the ability of state-of-the-art CGCMs in simulating the NWPAC. For climatology simulation, the weak mei-yu-baiuchangma rainfall and northward shift of NWP subtropical high are the common biases in CMIP models (Inoue and Ueda 2009; He and Zhou 2014; Song and Zhou 2014; He and Zhou 2015), which are related to the rainfall parameterization and air-sea interaction-caused meridional position of the intertropical convergence zone (ITCZ) over the tropical North Pacific (Qu 2017). Although some CMIP models could reproduce anomalous circulation and rainfall over the NWP, large intermodel spread still exists in interannual variability of NWPAC. In an analysis of CMIP3 models, Kosaka and Nakamura (2011) found that reproducibility of the Pacific-Japan teleconnection pattern in the model is highly associated with the simulation of climatological mean state over the NWP. Furthermore, the TIO warming plays a crucial role in modulating NWPAC in CMIP5 models (Song and Zhou 2014), and He and Zhou (2015) further emphasized the importance of zonal SST gradient between the TIO and the tropical WP. Furthermore, subsequent studies revealed the modulation of ENSO variability in the relationship between ENSO and East Asian summertime climate (Fu et al. 2013; K. Hu et al. 2014; Fu and Lu 2017). The relative strong interannual variability of ENSO strengthens its related atmospheric and oceanic processes, leading to a stronger response of TIO SST (Tao et al. 2015) and further amplifying the anomalous NWPAC (Hu et al. 2014). Moreover, with the unchanged ENSO activity under global warming, the TIO warming and NWPAC are enhanced during the decaying phase of ENSO (Zheng et al. 2011; K. Hu et al. 2014; Tao et al. 2015), although there is still debate 
regarding the future changes of the NWPAC (He et al. 2015; Yun et al. 2015; Wei Chen et al. 2016).

Recent studies based on output from the CMIP models evaluated the biases of TIO SST and NWP circulation response to ENSO (Tao et al. 2016; Jiang et al. 2017). Because of the compensation of errors in simulating ENSO-related atmospheric and oceanic processes, the TIO SST anomalies can persist through summer. However, the simulated NWPAC is weaker than observations, and this difference is attributed to unrealistic SST anomalies in the equatorial WP (Tao et al. 2016). Further analysis shows that the excessive westward extension of cold tongue increases climatology zonal SST gradient, which leads to anomalous zonal advection with the westerly wind anomalies and maintains the SST anomalies there (Jiang et al. 2017). While Jiang et al. (2017) revealed the possible mechanism involved in the maintenance of equatorial WP SST anomalies, they only emphasized the effect of zonal advection there during the decaying phase of ENSO. So, what causes the WP SST anomalies? And will the dominant processes change in the evolution of SST anomalies there? Furthermore, although the biases of NWPAC could be explained by the WP SST anomalies (Tao et al. 2016; Jiang et al. 2017), are there any other possible factors? Therefore, in the present study, we perform a comprehensive analysis on the NWPAC biases during ENSO decaying summer in CMIP5 models. An empirical orthogonal function (EOF) analysis is used to identify the leading modes of NWPAC biases. It is found that the NWPAC biases originate from ENSO-related SST anomalies over the equatorial WP and the whole Indo-Pacific sector, respectively. The sources of biases in SST anomalies are further investigated.

The rest of the paper is organized as follows. Section 2 describes the CMIP5 models, data, and methods. The leading two modes of NWPAC biases and their SST sources are obtained in section 3. Sections 4 and 5 respectively investigate the mechanisms involved in the biases of ENSO-related SST anomalies for the leading modes and further discuss with the climatology state. Section 6 provides a summary of the main findings.

\section{Data and methods}

The present study is based on historical scenario simulations of 32 CMIP5 models, which were forced by observed history of anthropogenic and natural forcing from 1870 to 2006. For detailed information on the models, please see http://cmip-pcmdi.llnl.gov/. In this study, 30 years of simulations covering 1970-99 are used as in Tao et al. (2016). Table 1 lists the names, institutions, and countries of the models. Monthly mean output is used, including SST, precipitation, atmospheric zonal and meridional winds, latent heat flux (LHF), sensible heat flux (SHF), net surface longwave radiation (LWR), net surface shortwave radiation (SWR), threedimensional (3D) ocean potential temperature, ocean zonal and meridional currents, and vertical mass transport. The net LWR and SWR are calculated as the difference between downward and upward LWR and SWR, respectively. Ocean vertical velocity is obtained from the ocean vertical mass transport. Only one member (r1i1p1) of each model simulations is analyzed. The observational datasets include the following: 1) the Hadley Centre Sea Ice and Sea Surface Temperature dataset (HadISST) with $1^{\circ} \times 1^{\circ}$ horizontal resolution covers the period from January 1870 to the present (Rayner et al. 2003); 2) monthly 850-hPa wind, LHF, SHF, LWR, and SWR from the National Centers for Environmental Prediction (NCEP)-National Center for Atmospheric Research (NCAR) reanalysis product with $2.5^{\circ} \times 2.5^{\circ}$ horizontal resolution cover the period from January 1948 to the present (Kalnay et al. 1996); 3) the Simple Ocean Data Assimilation (SODA) product, version 2.2 .4 , with $0.5^{\circ} \times 0.5^{\circ}$ horizontal resolution covers the period from January 1871 through December 2008 (Carton et al. 2005; Carton and Giese 2008); and 4) NOAA's Precipitation Reconstruction (PREC) data with $2.5^{\circ} \times 2.5^{\circ}$ horizontal resolution cover the period from January 1948 to the present (Chen et al. 2002). All CMIP5 output and observational datasets are interpolated to a uniform $2.5^{\circ} \times 2.5^{\circ}$ grid unless otherwise specified.

The monthly mean climatology is first calculated for the study period. Then, interannual anomalies are computed as the departure from the climatology. This study focuses on the interannual variability. To extract interannual signals, we perform a 3-month running average to reduce intraseasonal variability and remove the least squares trend in both model output and observations. Hereafter, any month in the developing years of ENSO is denoted by the suffix (0), whereas any month in the decaying years of ENSO is denoted by the suffix (1). DJF represents the seasonal mean in December-February, MAM represents the seasonal mean in March-May, and so on. Hereinafter, except otherwise specified, the intermodel difference is described as bias, and the difference between observation and model is described as difference. The Niño-3.4 index is defined as SST anomalies averaged over the region $5^{\circ} \mathrm{S}-$ $5^{\circ} \mathrm{N}, 170^{\circ}-120^{\circ} \mathrm{W}$ in December(0)-January-February(1) $[\mathrm{D}(0) \mathrm{JF}(1)]$.

EOF, regression, and correlation analysis are used in the present study. Note that, in observations, NWP circulation anomalies display obvious asymmetric characteristics between El Niño and La Niña. The asymmetric circulation response is related to the asymmetric SST anomalies (e.g., 
TABLE 1. The CMIP5 models used in this study. (Expansions of acronyms are available online at http://www.ametsoc.org/ PubsAcronymList.)

\begin{tabular}{|c|c|c|}
\hline No. & Model name & Institution (country) \\
\hline 1 & ACCESS1.0 & $\begin{array}{l}\text { Commonwealth Scientific and Industrial Research Organisation and Bureau of } \\
\text { Meteorology (Australia) }\end{array}$ \\
\hline 2 & BCC_CSM1.1 & Beijing Climate Center (China) \\
\hline 3 & BCC_CSM1.1(m) & \\
\hline 4 & CanCM4 & Canadian Centre for Climate Modelling and Analysis (Canada) \\
\hline 5 & CanESM2 & \\
\hline 6 & CCSM4 & National Center for Atmospheric Research (United States) \\
\hline 7 & CESM1(BGC) & \\
\hline 8 & CESM1(CAM5) & \\
\hline 9 & CESM1(FASTCHEM) & \\
\hline 10 & CESM1(WACCM) & \\
\hline 11 & $\mathrm{CMCC}-\mathrm{CM}$ & $\begin{array}{l}\text { Centre National de Recherches Météorologiques-Centre Européen de Recherche et } \\
\text { Formation Avancée en Calcul Scientifique (France) }\end{array}$ \\
\hline 12 & CNRM-CM5 & Centre National de Recherches Météorologiques (France) \\
\hline 13 & CSIRO Mk3.6.0 & $\begin{array}{l}\text { Commonwealth Scientific and Industrial Research Organisation in collaboration with } \\
\text { the Queensland Climate Change Centre of Excellence (Australia) }\end{array}$ \\
\hline 14 & FGOALS-g2 & $\begin{array}{l}\text { LASG, Institute of Atmospheric Physics, Chinese Academy of Sciences, and Center } \\
\text { for Earth System Science (CESS), Tsinghua University (China) }\end{array}$ \\
\hline 15 & GFDL CM3 & Geophysical Fluid Dynamics Laboratory (United States) \\
\hline 16 & GFDL-ESM2G & \\
\hline 17 & GFDL-ESM2M & \\
\hline 18 & GISS-E2-R & NASA Goddard Institute for Space Studies (United States) \\
\hline 19 & HadGEM2-CC & Met Office Hadley Centre (United Kingdom) \\
\hline 20 & HadGEM2-ES & \\
\hline 21 & INM-CM4.0 & Institute of Numerical Mathematics (Russia) \\
\hline 22 & IPSL-CM5A-LR & L'Institut Pierre-Simon Laplace (France) \\
\hline 23 & IPSL-CM5A-MR & \\
\hline 24 & IPSL-CM5B-LR & \\
\hline 25 & MIROC5 & Japan Agency for Marine-Earth Science and Technology, Atmosphere and Ocean \\
\hline 26 & MIROC-ESM & Research Institute (The University of Tokyo), and National Institute for \\
\hline 27 & MIROC-ESM-CHEM & Environmental Studies (Japan) \\
\hline 28 & MPI-ESM-LR & Max Planck Institute for Meteorology (MPI-M) (Germany) \\
\hline 29 & MPI-ESM-MR & \\
\hline 30 & MRI-CGCM3 & Meteorological Research Institute (Japan) \\
\hline 31 & NorESM1-M & Norwegian Climate Centre (Norway) \\
\hline 32 & NorESM1-ME & \\
\hline
\end{tabular}

Zhang et al. 1996; Wu et al. 2010a; Karori et al. 2013; Zhang et al. 2015; Tao et al. 2017), since El Niño tends to decay rapidly after the mature phase, whereas La Niña persists and reemerges in the subsequent year (Kessler 2002; Larkin and Harrison 2002; McPhaden and Zhang 2009; Z.-Z. Hu et al. 2014). However, ENSO asymmetry is underestimated in CMIP5 models (Zhang and Sun 2014), and the CEP warming and cooling persist into El Niño and La Niña decaying summer respectively, resulting in weak asymmetric SST anomalies. Correspondingly, the asymmetry of atmospheric response in CMIP5 models is much weaker than in observations (figure not shown). Furthermore, the leading modes of NWPAC biases for El Niño and La Niña in CMIP5 models are similar to regressed results (figure not shown). Therefore, the regression method used here is mostly valid, although ENSO asymmetry in reality is needed to keep in mind.
To understand the relative roles of ocean advection and surface heat flux terms in contributing to the bias of SST anomalies, the oceanic mixed layer heat budget is calculated. The mixed layer temperature tendency equation may be written as follows:

$$
\begin{aligned}
\frac{\partial T^{\prime}}{\partial t}= & -\left(u^{\prime} \frac{\partial \bar{T}}{\partial x}+v^{\prime} \frac{\partial \bar{T}}{\partial y}+w^{\prime} \frac{\partial \bar{T}}{\partial z}\right) \\
& -\left(\bar{u} \frac{\partial T^{\prime}}{\partial x}+\bar{v} \frac{\partial T^{\prime}}{\partial y}+\bar{w} \frac{\partial T^{\prime}}{\partial z}\right) \\
& -\left(u^{\prime} \frac{\partial T^{\prime}}{\partial x}+v^{\prime} \frac{\partial T^{\prime}}{\partial y}+w^{\prime} \frac{\partial T^{\prime}}{\partial z}\right)+\frac{Q_{\text {net }}^{\prime}}{\rho C_{P} H}+R,
\end{aligned}
$$

where $T$ denotes the mixed layer temperature; $u, v$, and $w$ are $3 \mathrm{D}$ ocean currents; $\partial / \partial x, \partial / \partial y$, and $\partial / \partial z$ represent the $3 \mathrm{D}$ gradient operator; $Q_{\mathrm{net}}^{\prime}$ represents the net heat 
flux (NHF) at the ocean surface (downward positive), which is the summation of LHF, SHF, net surface LWR, and net surface SWR; $\rho=10^{3} \mathrm{~kg} \mathrm{~m}^{-3}$ is the density of water; $C_{P}=4000 \mathrm{~J} \mathrm{~kg}^{-1} \mathrm{~K}^{-1}$ is the specific heat of water; $H \approx 50 \mathrm{~m}$ is the mixed layer depth, which is determined based on a temperature change of $0.5^{\circ} \mathrm{C}(\mathrm{Wu}$ and $\mathrm{Yeh}$ 2010; Wu et al. 2014b); and $R$ represents the residual term. A prime represents the interannual anomaly, and a bar represents the climatological mean. The first nine terms on the right-hand side of the equation are ocean advection terms, and the tenth term is surface heat flux terms. All of the mixed layer terms are calculated based on their depth average.

\section{Intermodel mode of NWPAC biases}

As mentioned before, summertime circulation anomalies over the NWP depend largely on the Indo-Pacific SST pattern during the ENSO decaying phase both in observations and models (e.g., Wu et al. 2010b; Wang et al. 2013; Z. Chen et al. 2016; Tao et al. 2016, 2017; Jiang et al. 2017; Liu et al. 2018; Xie and Zhou 2017). In this section, the simulation of NWPAC, precipitation, and SST in each model compared with observations is examined. We further extract the dominant modes of NWPAC biases, and analyze the relevant SST sources.

Figure 1 shows the regression of SST, 850-hPa wind, and precipitation with respect to $\mathrm{D}(0) \mathrm{JF}(1)$ Niño-3.4 index during JJA(1) for observations and CMIP5 models. In observations, the most significant feature of atmospheric circulation anomalies is a meridional tripole pattern extending from the eastern Indian Ocean (EIO) and tropical WP to NWP (Fig. 1, OBS). Beside the cyclonic wind anomalies over the EIO and tropical $\mathrm{WP}$, an anomalous anticyclone and cyclone are located north and south of $30^{\circ} \mathrm{N}$, respectively. Accordingly, rainfall anomalies also show a meridional tripole pattern, with positive rainfall anomalies covering a large tropical area from the EIO to central Pacific, negative rainfall anomalies over the NWP, and positive rainfall anomalies over the mei-yu-baiu-changma regions.

A tripole structure of SST anomalies is exhibited over the Indo-Pacific sector with warming over the equatorial CEP, and cooling over the WP and most of the northern and southern subtropical Pacific, which is a typical pattern in El Niño decaying phase. In addition, the SST anomalies over the TIO show a basinwide warming, which is a response to El Niño forcing through atmospheric and oceanic processes (e.g., Klein et al. 1999; Chiang and Sobel 2002; Xie et al. 2002; Lau and Nath 2003; Chiang and Lintner 2005; Du et al. 2009; Tao et al. 2014).
However, large intermodel spread exists in the 32 CMIP5 model simulations of ENSO-related JJA(1) circulation anomalies over the NWP. Among those models being able to capture the anomalous NWPAC, some reproduce a reasonable SST pattern as in observations, such as CESM1(FASTCHEM), CNRM-CM5, GISS-E2-R, and NorESM1-M (Fig. 1; models 9, 12, 18, and 31). Others show a stronger CEP and TIO warming than observations, indicating stronger ENSO in these models, such as CCSM4, GFDL-ESM2M, MIROC5, and NorESM1-ME (Fig. 1; models 6, 17, 25, and 32). In addition, local forcing appears to be important in CCSM4, GFDL-ESM2M, and MIROC5 because of a stronger and larger area of NWP cooling. Tao et al. (2016) have revealed that the equatorial WP SST anomalies persist longer than observations in some models, such as CSIRO Mk3.6.0, MPI-ESM-LR, and MPI-ESMMR (Fig. 1; models 13, 28, and 29), which is possibly related to the westward shift of the ENSO warm tongue (e.g., Collins et al. 2010; Kim and Yu 2012; Gong et al. 2015; Ham and Kug 2015; Huang et al. 2014; Zhang and Sun 2014; Tao et al. 2016; Tao et al. 2015; Jiang et al. 2017). As a result, there is an anomalous cyclone rather than an anticyclone over the NWP. Note that both the unrealistic SST anomalies over the NWP and equatorial WP exist in CanCM4 and CanESM2 (Fig. 1; models 4 and 5), and an excessive local SST forcing is detected in these two models (Hu and $\mathrm{Wu} 2015$ ).

To extract the dominant modes of NWPAC biases, an intermodel EOF analysis is applied to the regressed 850$\mathrm{hPa}$ wind anomalies over the NWP $\left(10^{\circ} \mathrm{S}-40^{\circ} \mathrm{N}, 90^{\circ} \mathrm{E}-\right.$ $170^{\circ} \mathrm{W}$ ) in CMIP5 models. Note that, before EOF analysis, regressed $850-\mathrm{hPa}$ zonal and meridional components for each model are first standardized respectively to enable a more efficient compaction of multifield data following the similar method of multivariate EOF analysis (Wang 1992). Furthermore, using a different NWP definition applied to EOF analysis, for instance a smaller region $\left(10^{\circ} \mathrm{S}-40^{\circ} \mathrm{N}, 90^{\circ} \mathrm{E}-180^{\circ}\right)$, would not alter the leading modes of NWPAC biases, further emphasizing that the main conclusions in present study are robust. Figure 2 shows the regression of SST, 850-hPa wind, and precipitation with respect to the leading two principal components (PCs) as well as the EOFs. The variances explained by the first two EOF patterns are well separated according to North et al. (1982).

\section{a. EOF1 mode}

The first EOF mode (EOF1; Fig. 2a), explaining 21.3\% of total intermodel variance, exhibits a meridional dipole structure of circulation anomalies from the EIO to NWP: An anomalous cyclone is located over the NWP, and an anomalous anticyclone is located northeastward. 

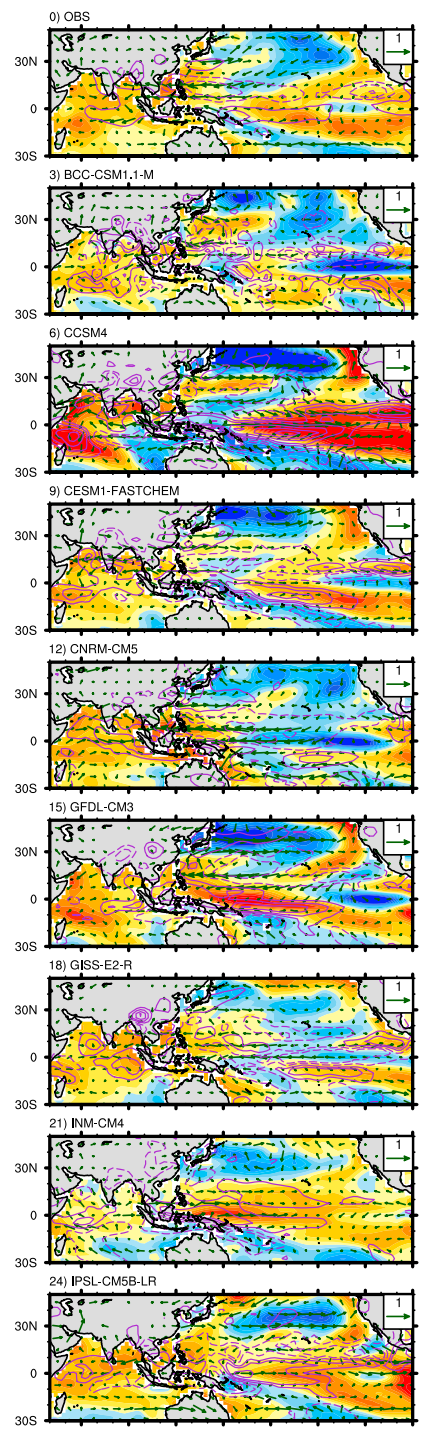

$305 \frac{1}{27) \text { MIROC-ESM-CHEM }}$
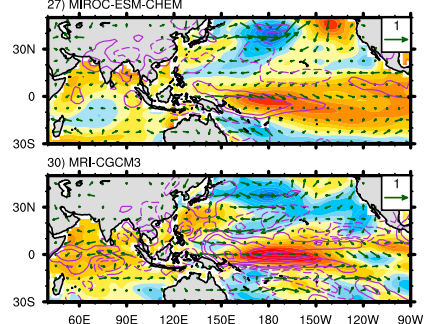
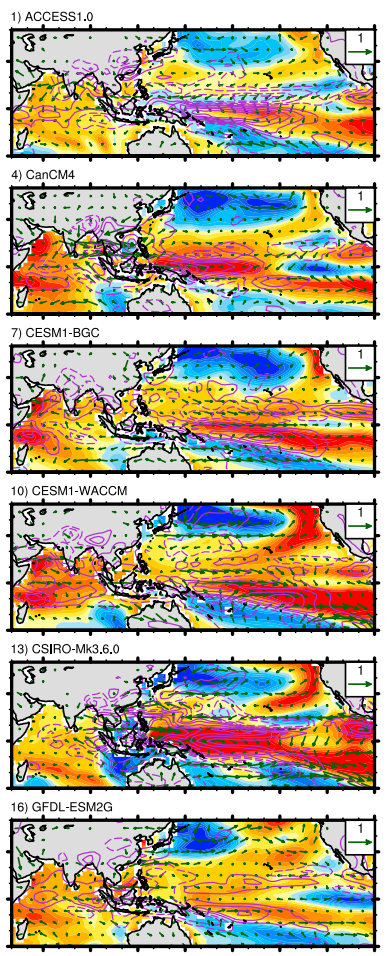

19) HadGEM2-CC
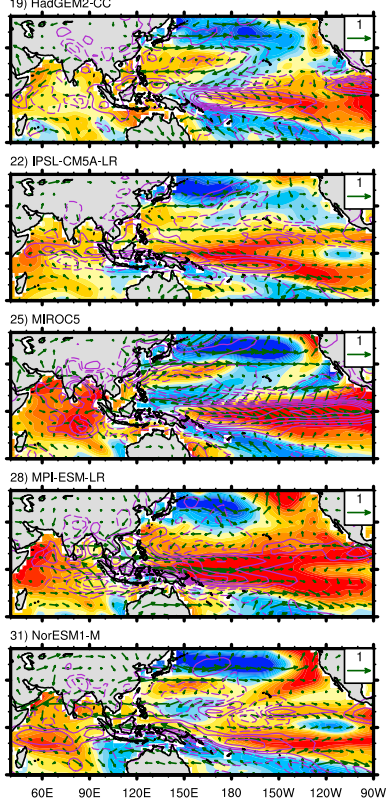
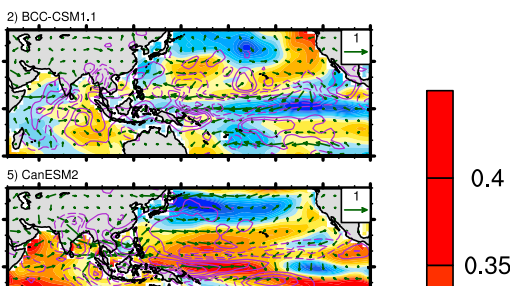

0.35
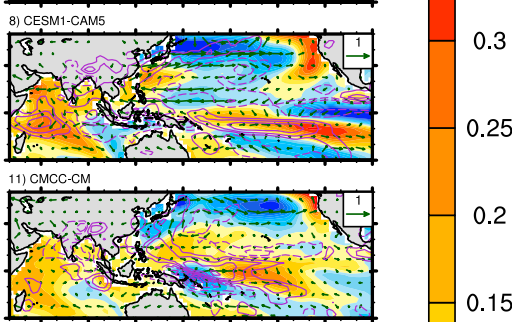

0.2

0.15

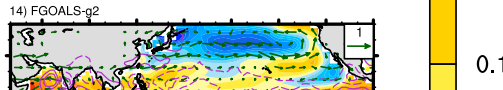

0.1

0.05
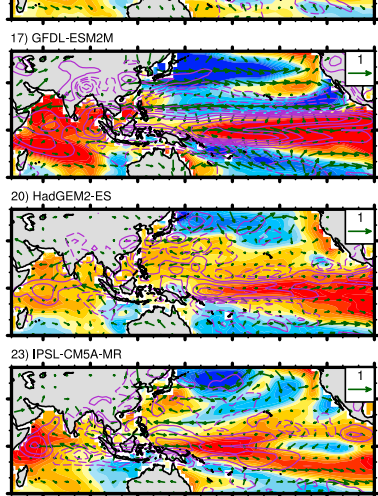

26) MIROC-ESM
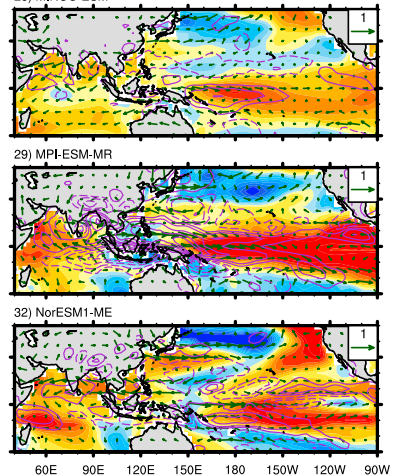

FIG. 1. Regression of SST (shaded; ${ }^{\circ} \mathrm{C}$ ), 850-hPa winds (vectors; $\mathrm{m} \mathrm{s}^{-1}$ ) and precipitation (contours, with contour intervals (CIs) of $\pm 0.2, \pm 0.5, \pm 1.0, \pm 1.5$, and $\pm 2.0 \mathrm{~mm}$; negative contours are dashed) with respect to $\mathrm{D}(0) \mathrm{JF}(1)$ Niño-3.4 index during JJA(1) for observation and CMIP5 models. Numbers 1-32 on the top left of the panels represent the model numbers listed in Table 1, and number 0 represents the observations.

Compared with Fig. 1 (OBS), the overall circulation distribution shifts slightly southward. For EOF1 mode, the cyclone there indicates the weaker simulation of NWPAC, and models with lower (higher) PC1 values would stimulate a better (worse) NWPAC.
The anomalous cyclone is a direct Rossby wave response to equatorial WP warming associated with positive rainfall anomalies, as there are no SST signals elsewhere (Fig. 2a). As Tao et al. (2016) and Jiang et al. (2017) mentioned, most CMIP models show unrealistic 

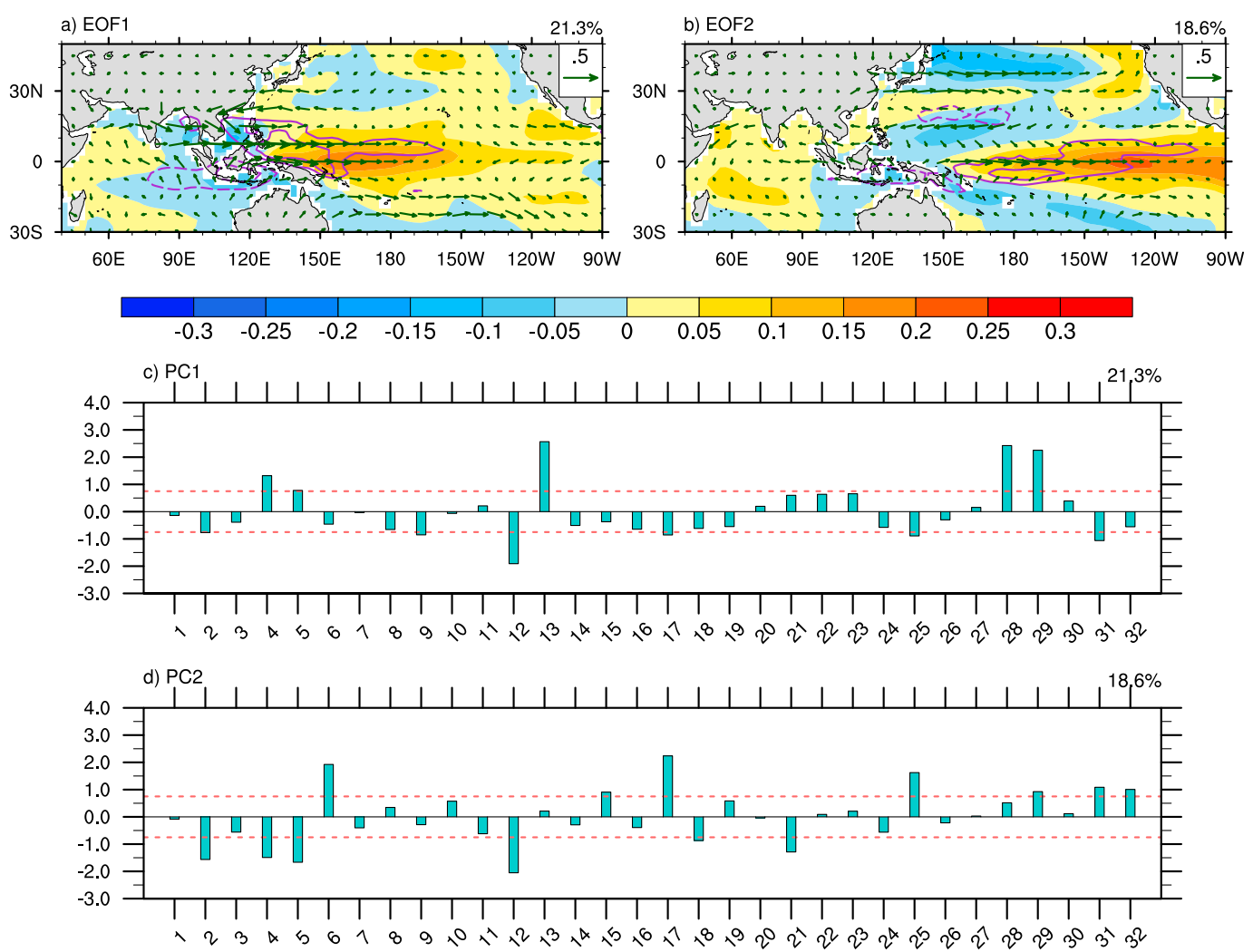

FIG. 2. Regression of regressed SST (shaded; ${ }^{\circ} \mathrm{C}$ ), 850 -hPa wind (vectors; $\mathrm{m} \mathrm{s}^{-1}$ ) and precipitation (contours, with $\mathrm{CI}= \pm 0.2, \pm 0.4, \pm 0.6$, and $\pm 1.0 \mathrm{~mm}$; negative contours are dashed) anomalies shown in Fig. 1 with respect to the standardized (a) PC1 and (b) PC2 of regressed $850-\mathrm{hPa}$ wind anomalies over the NWP $\left(10^{\circ} \mathrm{S}-40^{\circ} \mathrm{N}, 90^{\circ} \mathrm{E}-170^{\circ} \mathrm{W}\right)$ in CMIP5 models. Also shown are the standardized leading two PCs: (c) PC1 and (d) PC2. The explained variance fractions are given at the top right of the panels. The red dashed lines in (c),(d) represent the $0.75 \mathrm{std}$ dev.

SST anomalies over the equatorial WP during JJA(1). This feature is a common bias in CGCMs, most of which simulate an overly westward extended ENSO warm tongue (e.g., Collins et al. 2010; Kim and Yu 2012; Gong et al. 2015; Ham and Kug 2015; Huang et al. 2014; Zhang and Sun 2014; Tao et al. 2016; Jiang et al. 2017).

Here, the models with $\mathrm{PC} 1$ value above 0.75 are chosen as the positive $\mathrm{PC} 1$ value $(\mathrm{PC} 1+)$ models, and the models with $\mathrm{PC} 1$ value below -0.75 are chosen as the negative $\mathrm{PC} 1$ value $(\mathrm{PC1}-$ ) models (Fig. $2 \mathrm{c}$ ). As a result, there are five PC1+ models (CanCM4, CanESM2, CSIRO Mk3.6.0, MPI-ESM-LR, and MPI-ESM-MR) and six PC1- models [BCC_CSM1.1, CESM1(FASTCHEM), CNRM-CM5, GFDL-ESM2M, MIROC5, and NorESM1-M].

Figures $3 \mathrm{~b}$ and $3 \mathrm{c}$ show the composite maps for $\mathrm{PC} 1+$ and $\mathrm{PC} 1-$ models, respectively. The PC1 + models simulate a pattern similar to the EOF1 mode (Figs. 2a and $3 \mathrm{~b}$ ), and the PC1 - models capture the observed feature reasonably (Figs. 3a,c). The circulation anomalies over the NWP are completely different between $\mathrm{PC} 1+$ and PC1 - models, indicating that the unrealistic
SST anomalies over the equatorial WP largely influence the simulation of NWPAC (Tao et al. 2016; Jiang et al. 2017). The PC1 - models show a reasonable simulation of NWPAC, which is forced by the TIO warming and local cooling as the IPOC mode in observations (Xie et al. 2016; Xie and Zhou 2017). However, for PC1+ models, the unrealistic equatorial WP warming directly triggers the anomalous cyclone over the NWP as a Rossby wave response. Note that although there are SST anomalies over the TIO, they do not show the basinwide warming, and the effect of equatorial WP SST anomalies is dominant.

Figure 4 presents the relationship between PCs and SST anomalies. PC1 is largely controlled by SST anomalies over the equatorial WP, and the correlation coefficient between them is 0.87 , exceeding the $99 \%$ significance level (Fig. 4a). That is to say, the colder (warmer) SST anomalies over the equatorial WP tend to have a better (worse) simulation of the anomalous anticyclone, further emphasizing the importance of equatorial WP SST anomalies in EOF1 mode. 


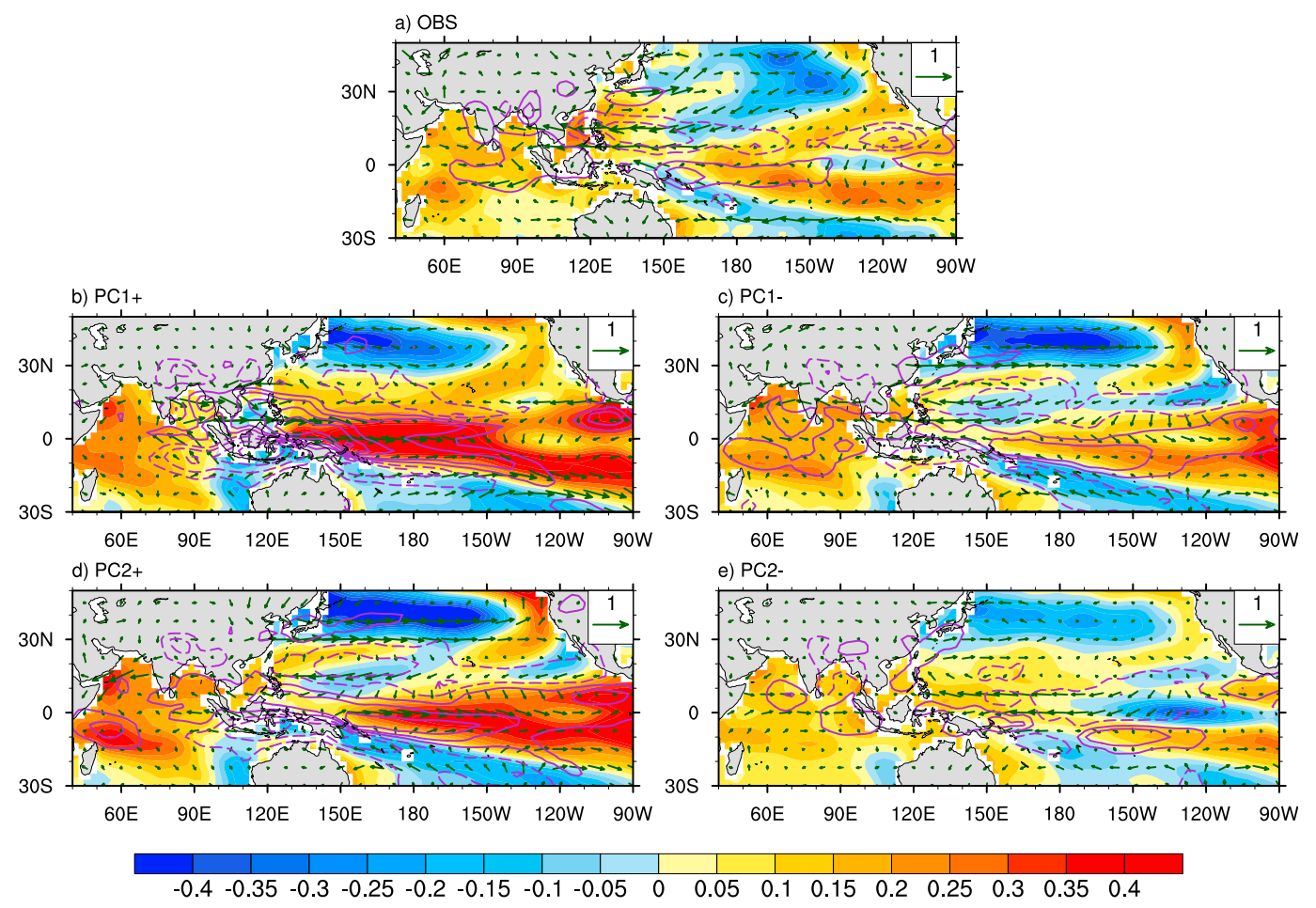

FIG. 3. Composite of SST (shaded; ${ }^{\circ} \mathrm{C}$ ), $850-\mathrm{hPa}$ winds (vectors; $\mathrm{m} \mathrm{s}^{-1}$ ) and precipitation (contours, with $\mathrm{CI}=$ $\pm 0.2, \pm 0.5, \pm 1.0, \pm 1.5$, and $\pm 2.0 \mathrm{~mm}$; negative contours are dashed) regressed onto $\mathrm{D}(0) \mathrm{JF}(1)$ Niño-3.4 index during JJA(1) for (a) observations and (b) PC1+, (c) PC1-, (d) PC2+, and (e) PC2- models.

\section{b. EOF2 mode}

The second EOF mode (EOF2; Fig. 2b), explaining $18.6 \%$ of total intermodel variance, exhibits a meridional dipole structure of circulation anomalies similar to that in the observations of Fig. 1 except for some differences in details. The cyclonic wind anomalies are mainly concentrated over the tropical WP, the NWPAC shifts northward, and the anomalous cyclone north of $30^{\circ} \mathrm{N}$ covers almost the whole North Pacific. For EOF2
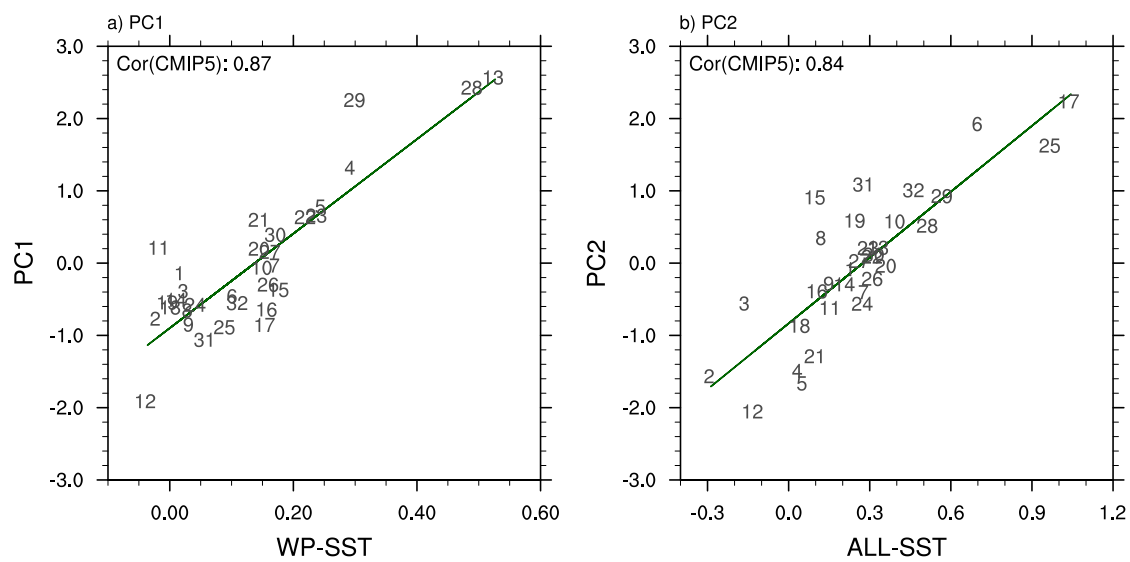

FIG. 4. Scatter diagram of (a) PC1 (ordinate) and SST anomalies over the equatorial WP (abscissa, ${ }^{\circ} \mathrm{C} ; 10^{\circ} \mathrm{S}-10^{\circ} \mathrm{N}, 150^{\circ} \mathrm{E}-170^{\circ} \mathrm{W}$ ) and (b) PC2 (ordinate) and SST anomalies over the Indo-Pacific sector (abscissa, ${ }^{\circ} \mathrm{C}$ ). The SST anomalies over the Indo-Pacific sector are calculated as the sum of equatorial CEP $\left(5^{\circ} \mathrm{S}-5^{\circ} \mathrm{N}, 170^{\circ}-120^{\circ} \mathrm{W}\right)$ and TIO $\left(20^{\circ} \mathrm{S}-20^{\circ} \mathrm{N}, 40^{\circ}-\right.$ $\left.100^{\circ} \mathrm{E}\right)$ warming minus NWP $\left(10^{\circ}-20^{\circ} \mathrm{N}, 130^{\circ} \mathrm{E}-180^{\circ}\right)$ cooling. Numbers indicate the model numbers listed in Table 1 . The green lines are the best fit lines for the model data. The correlation coefficients are on the top-left corner of each panel. 

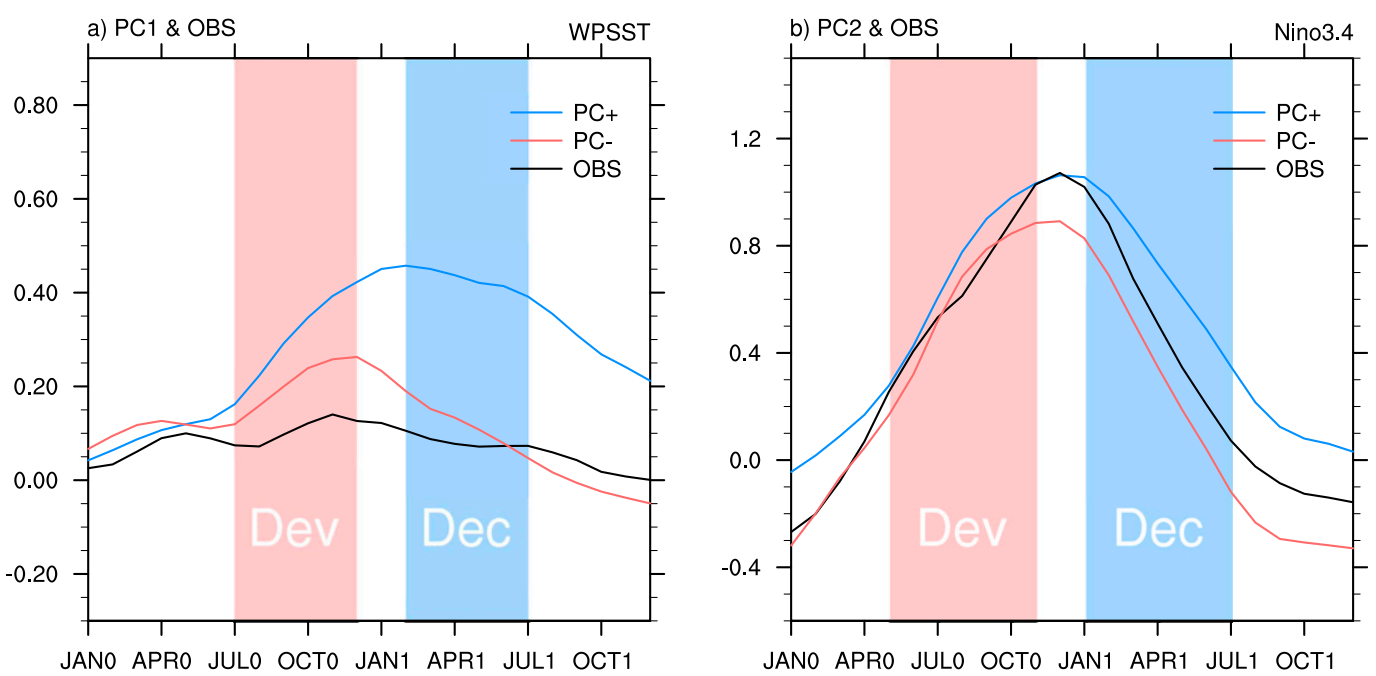

FIG. 5. Composite of (a) monthly SST anomalies over the equatorial WP $\left(10^{\circ} \mathrm{S}-10^{\circ} \mathrm{N}, 150^{\circ} \mathrm{E}-170^{\circ} \mathrm{W}\right)$ and (b) the monthly Niño-3.4 index regressed onto $\mathrm{D}(0) \mathrm{JF}(1)$ Niño-3.4 index for observations (black line), $\mathrm{PC}+$ models (blue line), and PC- models (red line). The red and blue shading labeled Dev and Dec represent the developing and decaying phase in the evolution of SST anomalies, respectively.

mode, the magnitude of PC2 values determines both the strength and location of NWPAC simulation, and models with higher (lower) PC2 values indicate a stronger (weaker) NWPAC with more (less) northward shift.

The SST anomalies feature a tripole pattern over the Indo-Pacific sector as observations. The SST anomalies are comparable over the equatorial CEP and TIO in observations, while equatorial CEP warming is stronger than TIO warming in the EOF2 mode. In addition, cold SST anomalies over the NWP cover a larger area, indicating an enhanced local forcing. The rainfall anomalies exhibit a dipole pattern over the tropical Pacific, and there are no obvious rainfall anomalies over the TIO. The TIO warming and NWP cooling characterize the IPOC mode, which contributes to the development of the NWPAC (Xie et al. 2016; Xie and Zhou 2017). Furthermore, the equatorial CEP warming could influence the location and intensity of NWPAC in JJA(1) through the Rossby wave-induced divergence mechanism, which resembles the effect of CEP cooling caused by the persistence of La Niña in observations (Tao et al. 2017). Although there is no significant rainfall response over the TIO, the local warming still can increase the tropospheric temperature by moist adiabatic adjustment (Chiang and Sobel 2002; Su et al. 2003; Chiang and Lintner 2005; Xie et al. 2009; K. Hu et al. 2014; Tao et al. 2015) and further contributes to maintenance of the NWPAC. The effect of TIO could also be demonstrated by divergence anomalies at upper levels, although its center shifts more westward than observation (figure not shown). The lack of rainfall anomalies over the TIO is possibly caused by the opposite roles of local and remote Pacific SST anomalies, as mentioned by $\mathrm{K}$. Hu et al. (2014) and Chowdary et al. (2017).

Here, the models with PC2 value above 0.75 are chosen as the positive $\mathrm{PC} 2$ value $(\mathrm{PC} 2+)$ models, and the models with $\mathrm{PC} 2$ value below -0.75 are chosen as the negative $\mathrm{PC} 2$ value (PC2-) models (Fig. 2d). There are seven $\mathrm{PC} 2+$ models (CCSM4, GFDL CM3, GFDLESM2M, MIROC5, MPI-ESM-MR, NorESM1-M, and NorESM1-ME) and six PC2- models (BCC_CSM1.1, CanCM4, CanESM2, GISS-E2-R, CNRM-CM5, and INM-CM4.0).

The composite maps for $\mathrm{PC} 2+$ and $\mathrm{PC} 2-$ models illustrate that the simulation of NWPAC is largely controlled by anomalous SST pattern over the Indo-Pacific sector (Figs. 3d and 3e, respectively). The PC2 + models show a similar pattern as EOF2 mode. There is an anomalous anticyclone over the NWP, with stronger SST and rainfall anomalies over the Indo-Pacific sector than observations (Fig. 3d). Also, the contribution of equatorial CEP SST anomalies is overestimated in $\mathrm{PC} 2+$ models (figure not shown). However, for PC2models, the warming over the equatorial CEP and TIO is weaker than in observations and $\mathrm{PC} 2+$ models, and there are warm rather than cold SST anomalies over the NWP for PC2- models (Figs. 3a,d,e). The relevant rainfall response is weak, and there are positive rainfall anomalies over the equatorial WP and South China Sea. As a result, there exists a weak anomalous cyclone over the South China Sea, and the upper-level convergence 

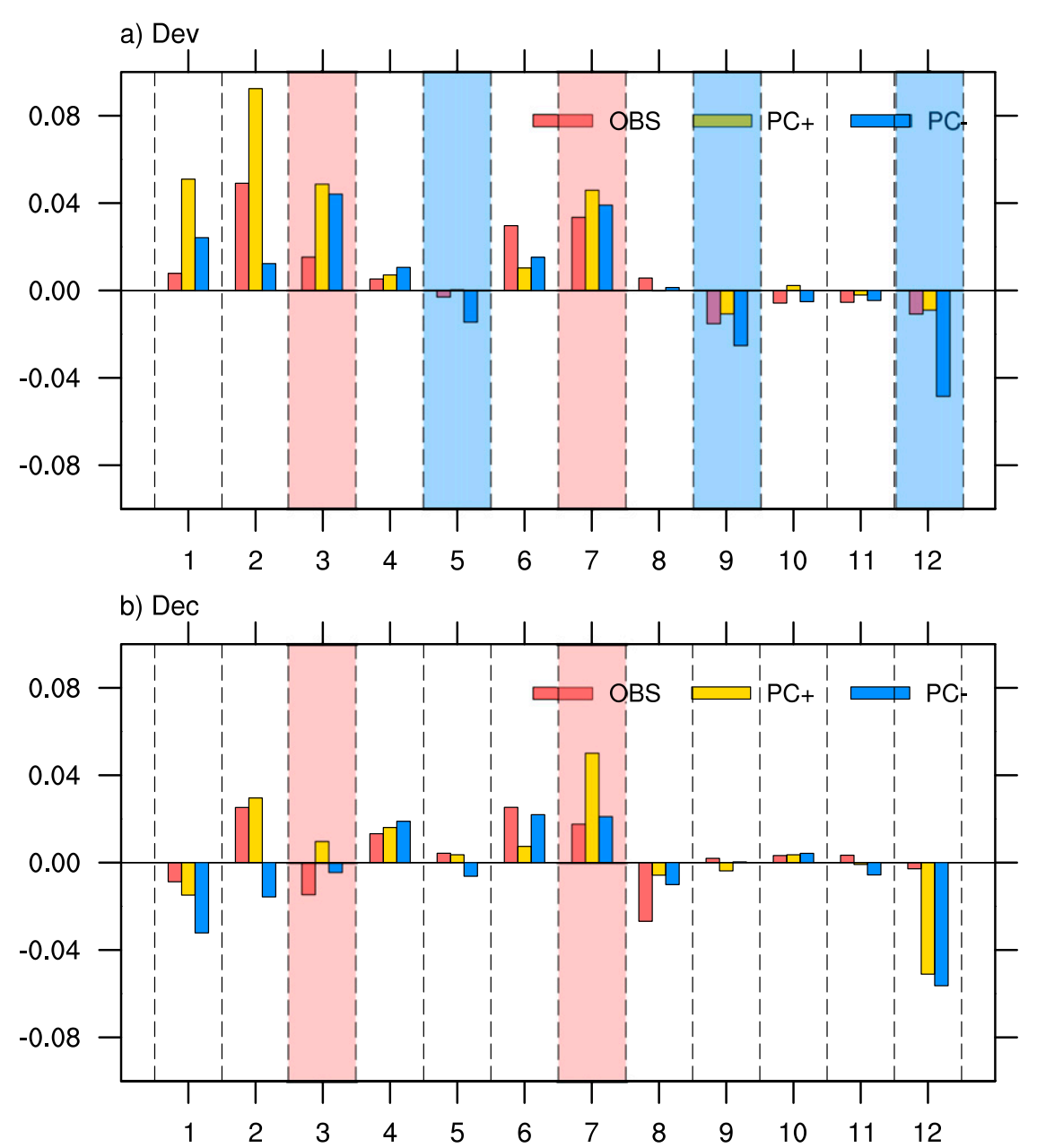

FIG. 6. Composite of mixed layer temperature budget terms $\left(\mathrm{K} \mathrm{month}^{-1}\right)$ during the (a) developing and (b) decaying phase in the evolution of equatorial WP $\left(10^{\circ} \mathrm{S}-10^{\circ} \mathrm{N}, 150^{\circ} \mathrm{E}-\right.$ $\left.170^{\circ} \mathrm{W}\right)$ SST anomalies for observations, PC1+ models, and PC1- models. Numbers 3-12 represent the terms $-u^{\prime} \partial \bar{T} / \partial x,-v^{\prime} \partial \bar{T} / \partial y,-w^{\prime} \partial \bar{T} / \partial z,-\bar{u} \partial T^{\prime} / \partial x,-\bar{v} \partial T^{\prime} / \partial y,-\bar{w} \partial T^{\prime} / \partial z$, $-u^{\prime} \partial T^{\prime} / \partial x,-v^{\prime} \partial T^{\prime} / \partial y,-w^{\prime} \partial T^{\prime} / \partial z$, and $Q_{\text {net }}^{\prime} / \rho C_{P} H$, respectively. No. 2 represents the sum of $3-12$, and No. 1 represents the term of $\partial T^{\prime} / \partial t$. For more details about the mixed layer temperature tendency equation, see section 2 . The red and blue shading represents the dominant positive and negative contribution, respectively.

center moves to the CEP (figure not shown), corresponding with southeast shift of NWPAC. It indicates that the SST pattern over the whole Indo-Pacific sector is important for simulating reasonable NWPAC in EOF2 mode.

Figure $4 \mathrm{~b}$ further demonstrates that $\mathrm{PC} 2$ is closely related to SST anomalies over the Indo-Pacific sector, and the correlation coefficient between them is 0.84 , which reaches the $99 \%$ significance level. That is to say, stronger (weaker) SST anomalies over the equatorial CEP, TIO, and NWP tend to produce a stronger (weaker) anomalous anticyclone with location shifted more (less) northward. Note that correlation coefficients between PC2 and SST anomalies in any one or two of the three regions are also calculated and lower than that using all the three regions.

As reviewed in the introduction, the SST anomalies over the Indo-Pacific sector could be largely explained by ENSO-induced atmospheric and oceanic processes, and the differences of the SST response there are controlled by different ENSO intensities (e.g., Klein et al. 1999; Chiang and Sobel 2002; Xie et al. 2002; Lau and Nath 2003; Chiang and Lintner 2005; Du et al. 2009; Tao et al. 2014). PC2 + and PC2 - models simulate larger and smaller SST anomalies over the equatorial CEP, TIO, and NWP than observations, suggesting stronger and weaker ENSO intensity, respectively. Therefore, the EOF2 mode reveals that the discrepancy of models from 

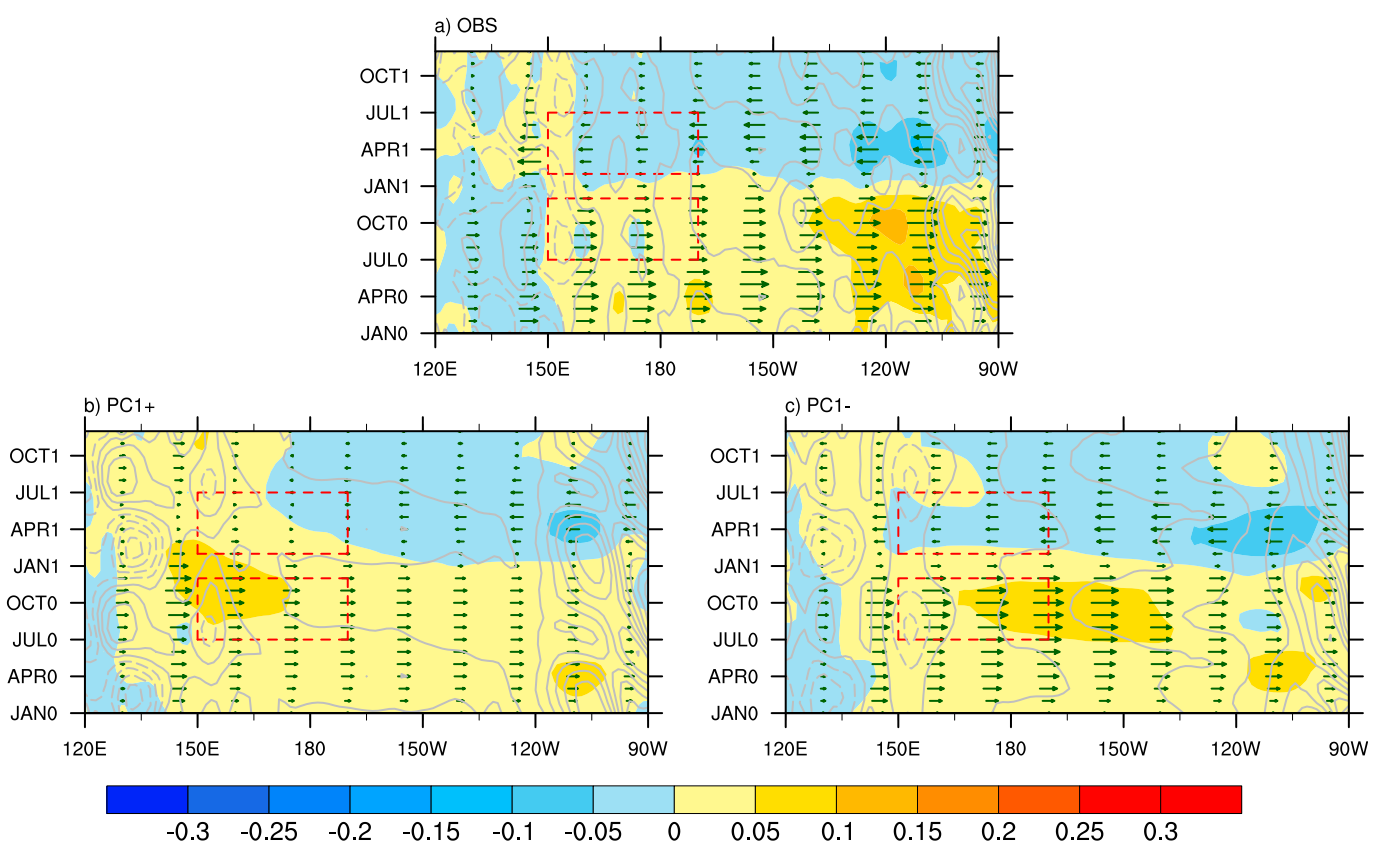

FIG. 7. Composite of mean temperature transported by anomalous zonal currents (shaded; $\mathrm{K}$ month ${ }^{-1}$ ), mean zonal temperature gradient (contours; $\mathrm{CI}$ is $0.5 \times 86400^{-1} \times 30^{-1} \mathrm{~K} \mathrm{~m}^{-1}$, and negative contours are dashed), and zonal ocean currents (vectors; $\mathrm{m} \mathrm{s}^{-1}$ ) regressed onto $\mathrm{D}(0) \mathrm{JF}(1)$ Niño-3.4 index, averaged over $10^{\circ} \mathrm{S}-10^{\circ} \mathrm{N}$ as a function of longitude and calendar month for (a) observations, (b) PC1+ models, and (c) PC1- models. Red dashed boxes represent longitude and month range for the developing and decaying phases.

observations in simulating ENSO intensity leads to NWPAC biases.

Kosaka et al. (2013) revealed that the NWPAC is the atmospheric manifestation of an air-sea coupled mode. Thus, the simulation of NWPAC could be affected by both the biases of internal variability and external forcing in models. However, in present study, the above analysis of the two leading modes suggests that the SST biases mainly contribute to NWPAC biases during the decaying phase of ENSO, and originate from two parts: One is related to the biases of SST anomalies over the equatorial WP, and the other depends on ENSO intensity. PC1+ models simulate unrealistic SST anomalies over the equatorial WP, and there is an anomalous cyclone rather than anticyclone over the NWP. In addition, $\mathrm{PC} 2+$ models simulate stronger ENSO and related larger SST response over the Indo-Pacific sector than PC2- models and tend to produce a stronger NWPAC with northward shift. We also apply an intermodel singular value decomposition (SVD) analysis between NWPAC biases $\left(10^{\circ} \mathrm{S}-40^{\circ} \mathrm{N}, 90^{\circ} \mathrm{E}-170^{\circ} \mathrm{W}\right)$ and SST biases $\left(20^{\circ} \mathrm{S}-20^{\circ} \mathrm{N}, 40^{\circ} \mathrm{E}-90^{\circ} \mathrm{W}\right)$, and the results of SVD analysis confirm those of EOF analysis, emphasizing the dominant contribution of SST biases (figure not shown). Thus, in sections 4 and 5 the possible mechanisms causing the biases of ENSO-related SST anomalies for EOF1 and EOF2 mode will be explored, respectively.

\section{Unrealistic equatorial WP SST anomalies}

The evolution of monthly SST anomalies over the equatorial WP for observation, PC1+ models, and PC1 - models is shown in Fig. 5a. Indeed, PC1 - models capture the weak equatorial WP SST anomalies, which is close to the observations. However, significant SST anomalies develop there from $\operatorname{July}(0)$ and persist through July(1) in PC1+ models, suggesting an overly westward extension of the ENSO warm tongue. In observations, some El Niño or La Niña events could persist long enough to produce another event (Z.-Z. Hu et al. 2014; Lee et al. 2014; Chowdary et al. 2017, 2016; Tao et al. 2017), such as the 1986-88 El Niño event and 19982000 La Niña event. However, in PC1+ models, the persisting SST anomalies extend more westward and reach the WP.

To better investigate the bias of overly westward extension in ENSO simulation and its development and persistence mechanism, a mixed layer heat budget analysis is conducted to diagnose the tendency of mixed layer temperature anomaly (MLTA) during the developing and decaying phase in the evolution of 
equatorial WP SST anomalies. Here, a developing (decaying) phase is from $\operatorname{July}(0)$ to December(0) [from February(1) to July(1)], as represented by the red (blue) shading in Fig. 5a. Figure 6 shows the regressed mixed layer temperature budget terms over the equatorial WP during the developing and decaying phase for observation, PC1 + models, and PC1- models. Note that the estimated MLTA tendency (term 2) is close to the actual temperature tendency (term 1 ), indicating that the mixed layer heat budget diagnosis results are credible.

During the developing phase, terms 3 and 7 make a major positive contribution to the development of unrealistic equatorial WP SST anomalies in PC1+ models (Fig. 6a). PC1 - models also show the stronger positive contribution than observations in these two terms, which are further compensated by the damping processes, as in terms 5, 9, and 12. Although the simulation of these terms in $\mathrm{PC} 1+$ models is comparable to observations, the weaker damping processes in $\mathrm{PC} 1+$ than $\mathrm{PC} 1-$ models could favor the development of equatorial WP SST anomalies to some extent. Moreover, the positive contribution of terms 3 and 7 in PC1+ models persists through the decaying phase (Fig. 6b). Note that, in these enhancing and damping processes, the discrepancies of terms 5,7 , and $9\left(-w^{\prime} \partial \bar{T} / \partial z,-\bar{v} \partial T^{\prime} / \partial y\right.$, and $-u^{\prime} \partial T^{\prime} / \partial x$, respectively) in observations and models are largely controlled by the anomalous parts involved in these terms (Figs. S1-S3 in the supplemental material), and could be further attribute to the different ocean temperature anomalies, indicating the self-adjustment of anomalous ocean temperature. The remaining two terms, terms 3 and 12, seem to be the key processes and will be analyzed in next subsection.

\section{a. Analysis for main processes}

Term $3\left(-u^{\prime} \partial \bar{T} / \partial x\right)$ is the advection of mean temperature by anomalous zonal currents, and Fig. 7 presents the composite maps of $-u^{\prime} \partial \bar{T} / \partial x$ and its related mean zonal temperature gradient $-\partial \bar{T} / \partial x$ and anomalous zonal currents $u^{\prime}$ as a function of longitude and calendar month for observations, PC1+ models, and PC1models. The center position of warm zonal advection displays a huge difference between observations and models. In PC1 + models, the positive values are located over the WP from developing to decaying phase (Fig. 7b) and largely contribute to the development and persistence of anomalous warm SST there (Figs. 6a,b). However, there are positive (negative) values over the eastern and central Pacific during the developing (decaying) phase in observations and PC1- models, respectively (Figs. 7a and 7c, respectively). Furthermore, the zonal advection is highly determined by the $-\partial \bar{T} / \partial x$ and $u^{\prime}$. Compared with observations and PC1 - models,

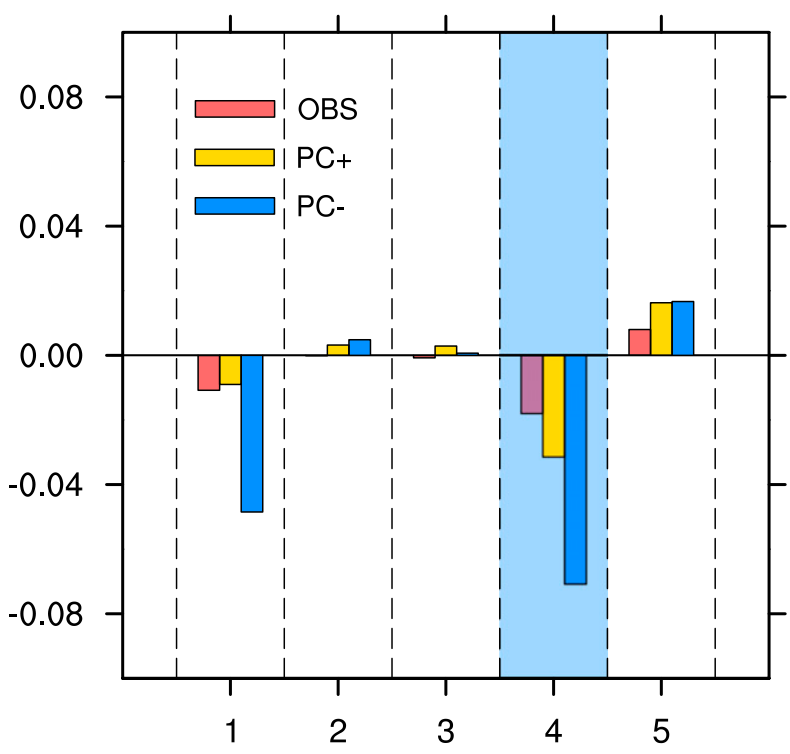

FIG. 8. Composite of surface NHF, LHF, SHF, LWR, and SWR (K month ${ }^{-1}$ ) contributing to the mixed layer temperature tendency during the developing phase in the evolution of equatorial WP $\left(10^{\circ} \mathrm{S}-10^{\circ} \mathrm{N}, 150^{\circ} \mathrm{E}-170^{\circ} \mathrm{W}\right)$ SST anomalies for observations, $\mathrm{PC} 1+$ models, and $\mathrm{PC} 1-$ models. Numbers 1-5 represent the terms $Q^{\prime}{ }_{\text {net }} / \rho C_{P} H, Q^{\prime}{ }_{\mathrm{lh}} / \rho C_{P} H, Q_{\mathrm{sh}}^{\prime} / \rho C_{P} H, Q_{\mathrm{sw}}^{\prime} / \rho C_{P} H$, and $Q^{\prime}{ }_{\mathrm{lw}} / \rho C_{P} H$, respectively. The blue shading represents the dominant contribution.

$-\partial \bar{T} / \partial x$ and $u^{\prime}$ are mainly concentrated over the WP in $\mathrm{PC} 1+$ models. The bias of $-\partial \bar{T} / \partial x$ originates from mean ocean temperature, and the bias of $u^{\prime}$ is coupled with anomalous ocean temperature. The results are partly consistent with Jiang et al. (2017), who emphasized the importance of $-u^{\prime} \partial \bar{T} / \partial x$ in maintaining equatorial WP SST anomalies during the decaying phase. Furthermore, we also point out its crucial role in causing the SST anomalies there.

PC1 - models capture the strongest cooling effect of NHF (term 12, $Q^{\prime}{ }_{\text {net }} / \rho C_{P} H$ ) during the developing phase, and the simulation of $Q^{\prime}{ }_{\text {net }} / \rho C_{P} H$ in $\mathrm{PC} 1+$ models is comparable to observations (Fig. 6a). Moreover, the NHF could be given by $Q_{\text {net }}=Q_{\mathrm{lh}}+Q_{\mathrm{sh}}+$ $Q_{\mathrm{lw}}+Q_{\mathrm{sw}}$, where $Q_{\mathrm{lh}}, Q_{\mathrm{sh}}, Q_{\mathrm{lw}}$, and $Q_{\mathrm{sw}}$ are the LHF, SHF, LWR, and SWR, respectively. As shown in Fig. 8, SWR dominates in the four terms. The composite maps of $Q^{\prime}{ }_{\text {net }} / \rho C_{P} H$ and $Q^{\prime}{ }_{\text {sw }} / \rho C_{P} H$ as a function of longitude and calendar month for observations, $\mathrm{PC} 1+$ models, and PC1 - models are shown in Fig. 9. Indeed, the pattern of NHF anomalies is consistent with the pattern of SWR both in observations and models. Compared with observations and PC1+ models, the SWR anomalies over the central Pacific are overestimated in PC1models, leading to excessive damping effect of NHF there (Figs. 9a-c). The SWR is highly associated with the 


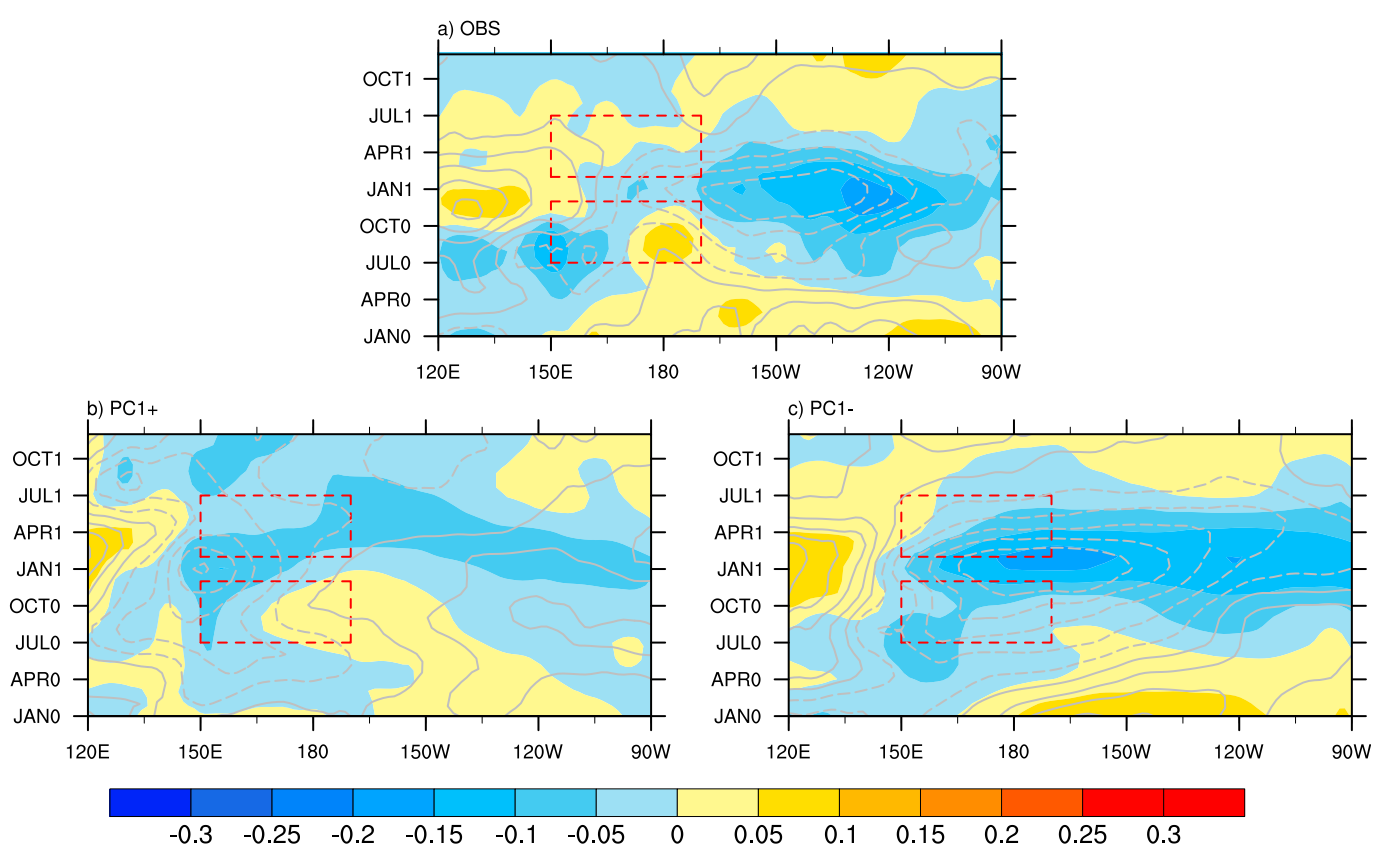

FIG. 9. Composite of surface NHF (shaded; $\mathrm{K} \mathrm{month}^{-1}$ ) and SWR (contours; $\mathrm{CI}$ is $0.02 \times 86400^{-1} \times 30^{-1} \mathrm{~K} \mathrm{~m}^{-1}$, and negative contours are dashed) contributing to the mixed layer temperature tendency regressed onto $\mathrm{D}(0) \mathrm{JF}(1)$ Niño-3.4 index, averaged over $10^{\circ} \mathrm{S}-10^{\circ} \mathrm{N}$ as a function of longitude and calendar month for (a) observations, (b) PC1+ models, and (c) PC1- models. Red dashed boxes represent longitude and month range for the developing and decaying phases.

rainfall or cumulus convection over the tropic via the SST-SWR feedback (Ramanathan and Collins 1991), which is further related to the simulation of SST and will be discussed in the next subsection. Note that, using a different time period or surface heat fluxes from the Objectively Analyzed Air-Sea Fluxes (OAFlux; Yu and Weller 2007) project, the 40-yr European Centre for Medium-Range Weather Forecasts (ECMWF) ReAnalysis (ERA-40; Uppala et al. 2005), and the National Oceanography Centre Southampton Flux Dataset, version 2.0 (NOCSv2.0; Berry and Kent 2009), does not alter major conclusions, such as the significant damping effect of NHF, the dominant role of SWR, and large difference between $\mathrm{PC} 1+$ and $\mathrm{PC1}-$ models in $Q^{\prime}{ }_{\text {net }} / \rho C_{P} H$ and $Q_{\text {sw }}^{\prime} / \rho C_{P} H$ (Fig. S4 in the supplemental material).

\section{b. Tracking back to climatology mean state}

As shown in the above two subsections, the unrealistic equatorial WP SST anomalies in PC1+ models are mainly affected by $-u^{\prime} \partial \bar{T} / \partial x$, and this term persists through the decaying phase. PC1- models also show stronger positive contribution than observations in this term, which is further compensated by the damping effect of $Q^{\prime}{ }_{\text {net }} / \rho C_{P} H$. The weak damping process in PC1+ models could favor the development of equatorial WP SST anomalies somewhat.
Those two key processes, both $-u^{\prime} \partial \bar{T} / \partial x$ and $Q^{\prime}{ }_{\text {net }} / \rho C_{P} H$, are controlled by mean and anomalous ocean temperature. Moreover, the simulation of ENSO-related ocean temperature anomalies is often determined by the mean state (e.g., Guilyardi 2006; Spencer et al. 2007; Jin et al. 2008; Magnusson et al. 2013; Kim et al. 2014). Thus, Fig. 10 presents the 3D structure of mean ocean temperature and currents, and their differences with PC1+ models and PC1- models, respectively. Compared with observations, PC1+ models represent cold SST differences along with insufficient precipitation and easterly winds (Fig. 10b), suggestive of an excessive equatorial Pacific cold tongue (Yu and Mechoso 1999; Luo et al. 2005; Zheng et al. 2012; Li and Xie 2014; Li et al. 2015). Moreover, excessive precipitation differences exist over much of the North and South Pacific, which is related to the doubleITCZ problem (Zhang and Wang 2006; Hirota et al. 2011; Hwang and Frierson 2013). The similar differences are present in $\mathrm{PC} 1-$ models but with weak intensity (Fig. 10c).

Because of the excessive equatorial Pacific cold tongue in PC1+ models, ENSO-related warming is hard to increase convection effectively. Thus, the rainfall response is weakened and reduces the downward SWR anomalies, which favor the development of equatorial WP SST anomalies. However, owing to weak SST differences in 

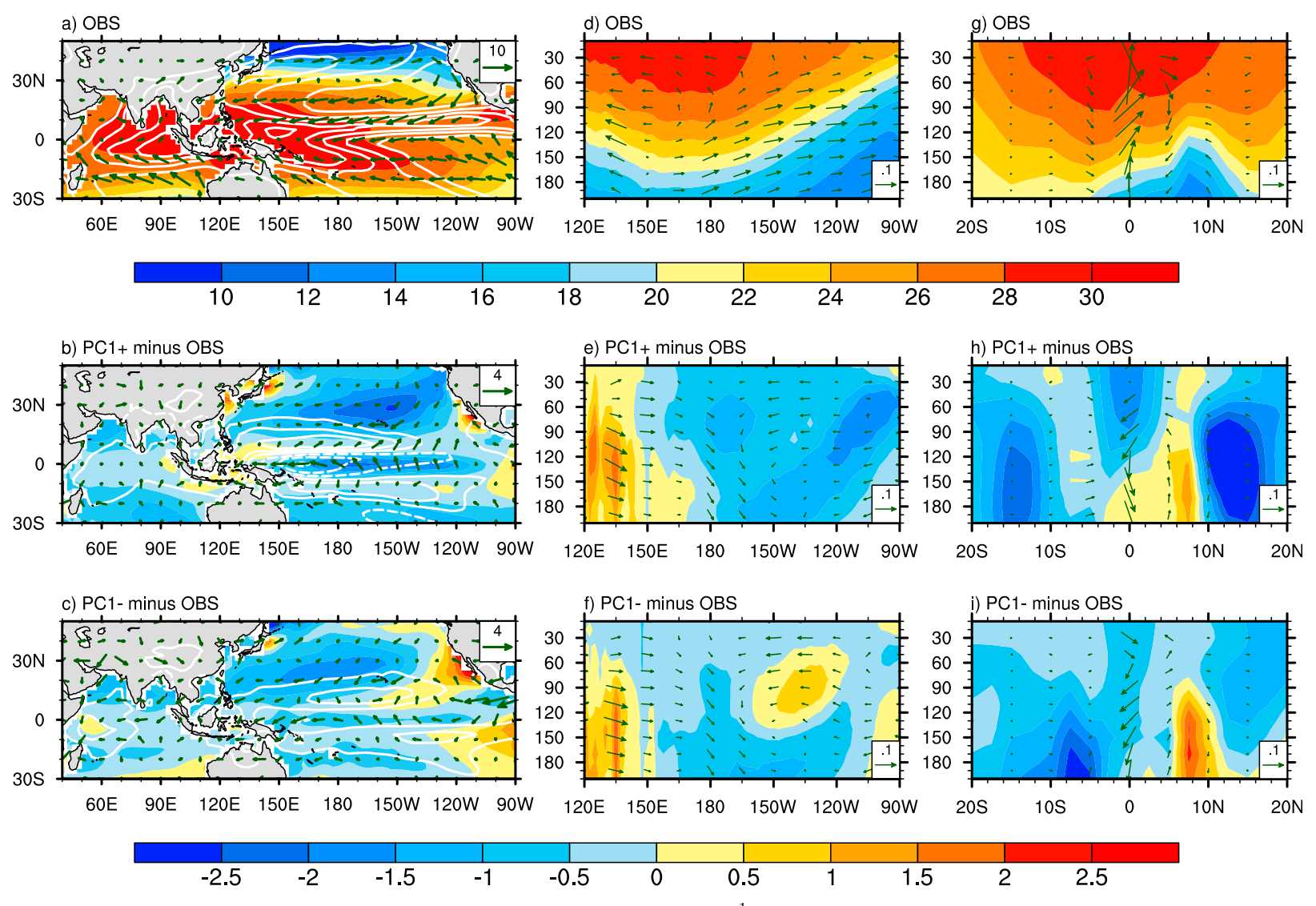

FIG. 10. (a) Annual mean SST (shaded; ${ }^{\circ} \mathrm{C}$ ), 1000-hPa winds (vectors; $\mathrm{m} \mathrm{s}^{-1}$ ), and precipitation (contours; $\mathrm{mm}$ ) in observations, and its difference with (b) PC1 + models (PC1+ models minus observations), and (c) PC1 - models (PC1- models minus observations). Contours for precipitation are drawn with a CI of $1.5 \mathrm{~mm}(2.0,3.5,5.0,6.5,8.0,9.5$, and $11.0 \mathrm{~mm})$ in (a) and $1.5 \mathrm{~mm}( \pm 1.0, \pm 2.5$, and $\pm 4.0 \mathrm{~mm}$, negative contours are dashed) in (b), (c). (d) Annual mean ocean temperature (shaded; ${ }^{\circ} \mathrm{C}$ ) and currents (vectors; $u$ is $\mathrm{m} \mathrm{s}^{-1}$, and $w$ is scaled by $\left.20000^{-1} \mathrm{~m} \mathrm{~s}^{-1}\right)$ along the equator $\left(10^{\circ} \mathrm{S}-10^{\circ} \mathrm{N}\right)$, and the difference with (e) PC1+ and (f) PC1 - models. (g) Annual mean ocean temperature (shaded; ${ }^{\circ} \mathrm{C}$ ) and currents (vectors; $v$ is $\mathrm{m} \mathrm{s}^{-1}$, and $w$ is scaled by $20000^{-1} \mathrm{~m} \mathrm{~s}^{-1}$ ) averaged over the equatorial WP $\left(150^{\circ} \mathrm{E}-\right.$ $170^{\circ} \mathrm{W}$ ), and its difference with (h) PC1 + and (i) PC1 - models.

PC1 - models, rainfall anomalies are more sensitive to anomalous SST, indicating a stronger SST-SWR feedback than PC1+ models. Also, as shown in section 4a, $-u^{\prime} \partial \bar{T} / \partial x$ partly depends on the zonal structure of climatology mean temperature, and $-\partial \bar{T} / \partial x$ is increased as a result of cold ocean temperature biases in $\mathrm{PC} 1+$ models. As a result, unrealistic equatorial WP SST anomalies in models could be attributed to the equatorial Pacific cold tongue bias.

Previous studies revealed that the excessive equatorial Pacific cold tongue and double-ITCZ problem are partly related (Neelin et al. 1992; Mechoso et al. 1995; de Szoeke et al. 2007; Lin 2007). The causes of these model problems are still in dispute, as some studies emphasized the atmospheric origins ( $\mathrm{Yu}$ and Mechoso 1999; Luo et al. 2005) and some indicated that the errors might come from the ocean models ( $\mathrm{Li}$ and Xie 2014; Li et al. 2015), and others revealed the importance of air-sea feedback (Lin 2007). However, in contrast to the previous studies (Li and Xie 2014; Li et al. 2015), Bjerknes feedback does not seem to work here (Figs. 10e,f,h,i). Although there is no obvious difference in ocean currents between $\mathrm{PC} 1+$ and $\mathrm{PC} 1-$ models, the ocean heat advection could cause the equatorial Pacific cold tongue bias resulting from erroneous subsurface temperature structure in PC1 + models, as mentioned by Zheng et al. (2012). Also, the atmospheric origins, as LHF and SWR and their related SST-LHF and SST-SWR feedbacks, might also make a contribution. Further analysis of the biases in climatology state is beyond the scope of this study and should be discussed in the future.

\section{ENSO intensity}

As shown in Fig. 5b, ENSO intensity is comparable between observation and $\mathrm{PC} 2+$ models at its mature 
a) Dev

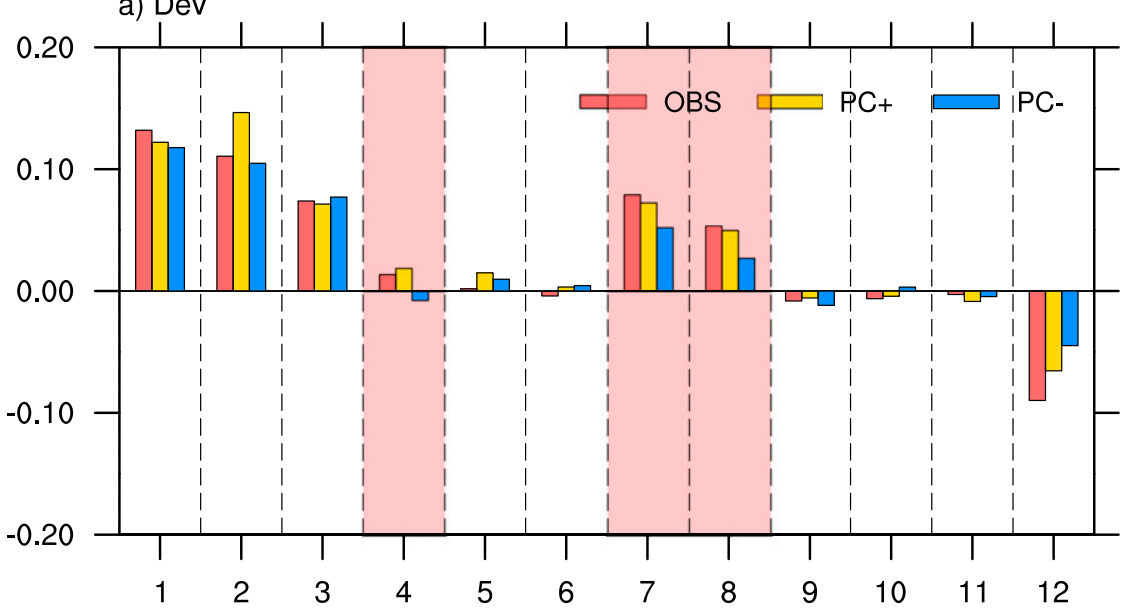

b) Dec

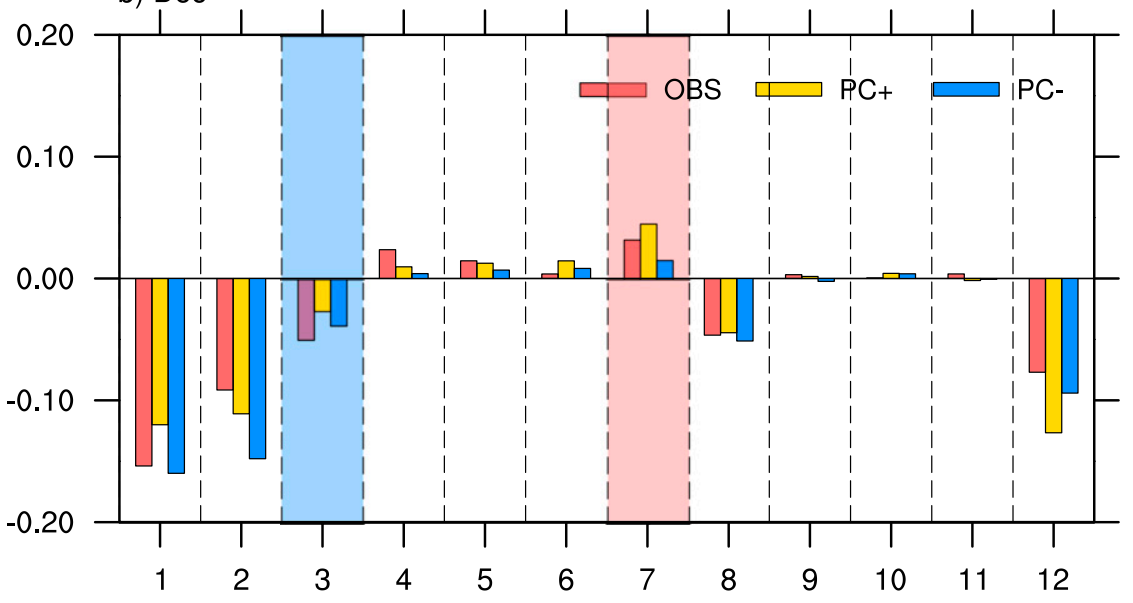

Fig. 11. As in Fig. 6, but for equatorial CEP SST anomalies $\left(5^{\circ} \mathrm{S}-5^{\circ} \mathrm{N}, 170^{\circ}-120^{\circ} \mathrm{W}\right)$ in observations, $\mathrm{PC} 2+$ models, and PC2 - models.

phase, and PC2 - models simulate the weakest ENSO. In addition, $\mathrm{PC} 2+$ and $\mathrm{PC} 2-$ models capture the slowest and fastest ENSO decaying pace, respectively. This is consistent with Lee et al. (2014), who found that strong El Niño event tends to persist into the boreal spring, whereas a weak El Niño favors a rapid decay shortly after its peak in the first mode of inter-El Niño variability. Feng et al. (2014) revealed that Pacific decadal oscillation (PDO) could modulate the relationship between ENSO and the NWPAC through the decaying pace of El Niño, and the slow and fast decaying pace correspond to the high and low PDO phase, respectively. However, in present study, both observation and models are in the high PDO phase (Figs. 3a,d,e), which does not seem to cause the different ENSO decaying pace. The discrepancies in ENSO intensity and its evolution feature in observation and models are investigated to further explore the relevant mechanism. Here, a developing (decaying) phase is from May(0) to November(0) [from January(1) to July(1)], as represented by the red (blue) shading in Fig. 5 b.

The regressed mixed layer temperature budget terms for CEP SST anomalies during the developing and decaying phase for observation, $\mathrm{PC} 2+$ models, and PC2 - models are shown in Fig. 11. During the developing phase, the discrepancies of terms 4,7 , and 8 in observations and models contribute to the different development of equatorial CEP SST anomalies and cause discrepancies in ENSO intensity (Fig. 11a). The enhancing effect of term 7 persists through the decaying phase, along with the damping effect of term 3, causing the different ENSO decaying pace (Fig. 11b). Actually, terms 3 and $4\left(-u^{\prime} \partial \bar{T} / \partial x\right.$ and $\left.-v^{\prime} \partial \bar{T} / \partial y\right)$ are controlled by $u^{\prime}$ and $v^{\prime}$ respectively (Figs. S5 and S6 in the supplemental material), which are coupled with anomalous ocean temperature, and these two terms reflect the 

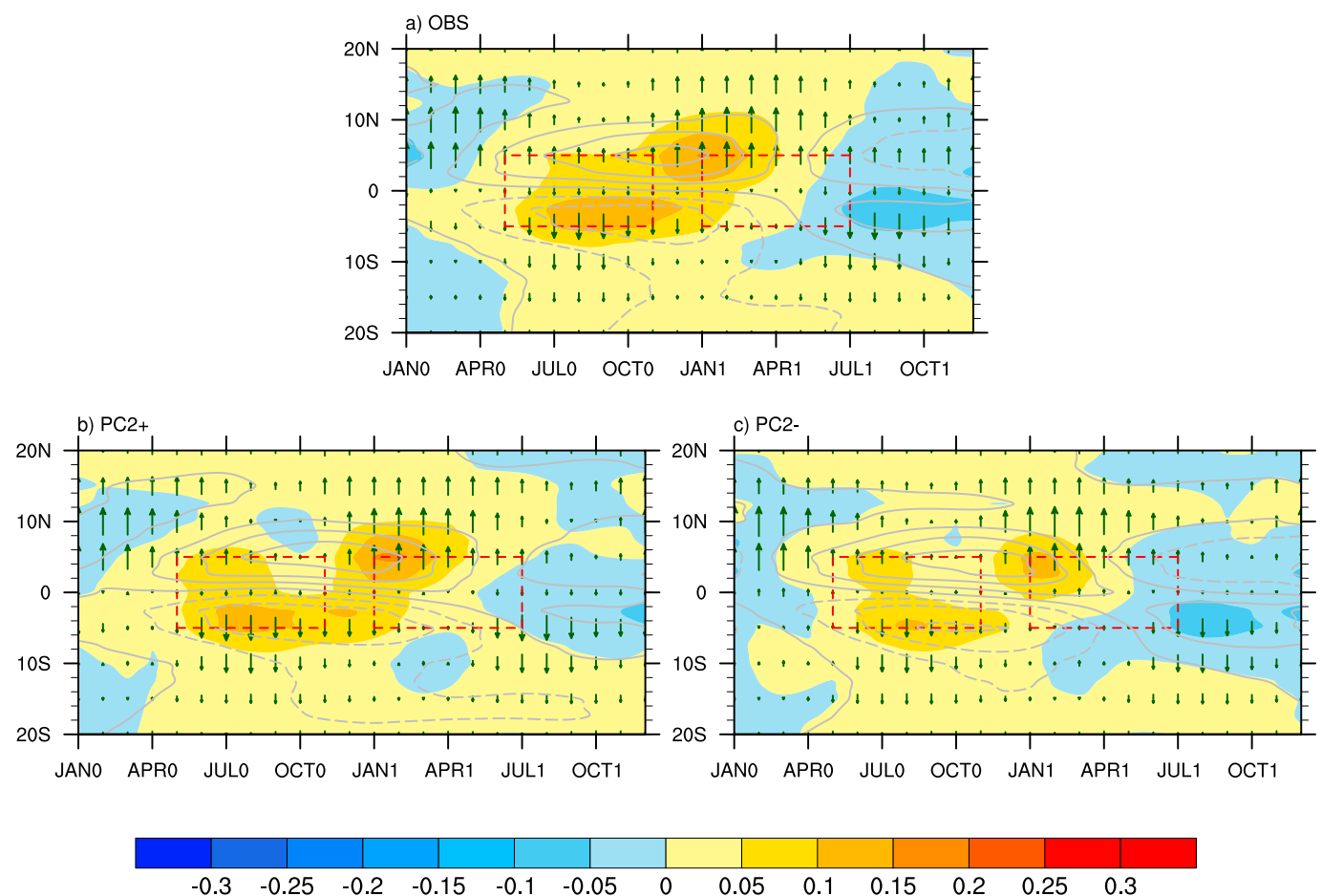

FIG. 12. Composite of anomalous temperature transported by mean meridional currents (shaded; $\mathrm{K} \mathrm{month}^{-1}$ ), meridional temperature gradient (contours; $\mathrm{CI}$ is $0.4 \times 86400^{-1} \times 30^{-1} \mathrm{~K} \mathrm{~m}^{-1}$, and negative contours are dashed) regressed onto $\mathrm{D}(0) \mathrm{JF}(1)$ Niño-3.4 index, and mean meridional ocean currents (vectors; $\mathrm{m} \mathrm{s}^{-1}$ ) averaged over $170^{\circ}-$ $120^{\circ} \mathrm{W}$ as a function of calendar month and latitude for (a) observations, (b) PC1 + models, and (c) PC1 - models. Red dashed boxes represent month range and latitude for the developing and decaying phases.

self-adjustment of ENSO. Terms 7 and 8 will be further explored.

\section{a. Analysis for main processes}

Here, term $7\left(-\bar{v} \partial T^{\prime} / \partial y\right)$, as the advection of anomalous temperature by mean meridional currents, plays a crucial role in the evolution of equatorial CEP SST anomalies during the two phases (Figs. 11a and 11b, respectively). Although anomalous ocean temperature lasts slightly longer in $\mathrm{PC} 2+$ models than in $\mathrm{PC} 2-$ models and observation, there is no significant discrepancy of $-\partial T^{\prime} / \partial y$ values in observation and models (Figs. 12a-c). Moreover, $\bar{v}$ is the weakest in PC2- models, and comparable in $\mathrm{PC} 2+$ models and observations. Thus, PC2 - models simulate the weakest $-\bar{v} \partial T^{\prime} / \partial y$, and the discrepancy of this term originates from the bias of $\bar{v}$.

Figure 13 presents the composite of anomalous temperature transported by mean vertical currents (term 8 , $-\bar{w} \partial T^{\prime} / \partial z$ ), which depends on the vertical structure of anomalous ocean temperature $-\partial T^{\prime} / \partial z$ and mean upwelling velocity $\bar{w}$, and indicates the thermocline feedback. Both $-\partial T^{\prime} / \partial z$ and $\bar{w}$ are weaker in PC2- models than the other two groups, leading to the weaker thermocline response (Figs. 11a and 13a-c).

\section{b. Tracking back to climatology mean state}

As shown in the previous two subsections, $-\bar{v} \partial T^{\prime} / \partial y$ and $-\bar{w} \partial T^{\prime} / \partial z$ in the developing phase are important in causing the discrepancies in ENSO intensity and its evolution features in observations and models, and thus the related $\bar{v}$ and $\bar{w}$ seem to be a key problem. Figure 14 presents the 3D structure of mean ocean temperature and currents, and its difference with PC2 + models and PC2models, respectively. In observations, both the zonal and meridional-vertical cross sections of mean ocean currents show the significant upwelling over the equatorial CEP (Figs. 14b,c). Corresponding to the poleward currents at the surface and equatorward flow at the subsurface, it forms two meridional overturning circulations, called the subtropical cells (STCs; McCreary and Lu 1994). PC2+ models do not show notable differences of ocean currents with observations (Figs. 14e, h). However, for PC2models, the upwelling over the equatorial CEP is much weaker than observation (Fig. 14h), and the difference of STCs shows reverse meridional overturning circulation, indicating the weak intensity of STCs (Fig. 14i).

Previous studies have shown that STCs could affect the ENSO amplitude and variability (Kleeman et al. 

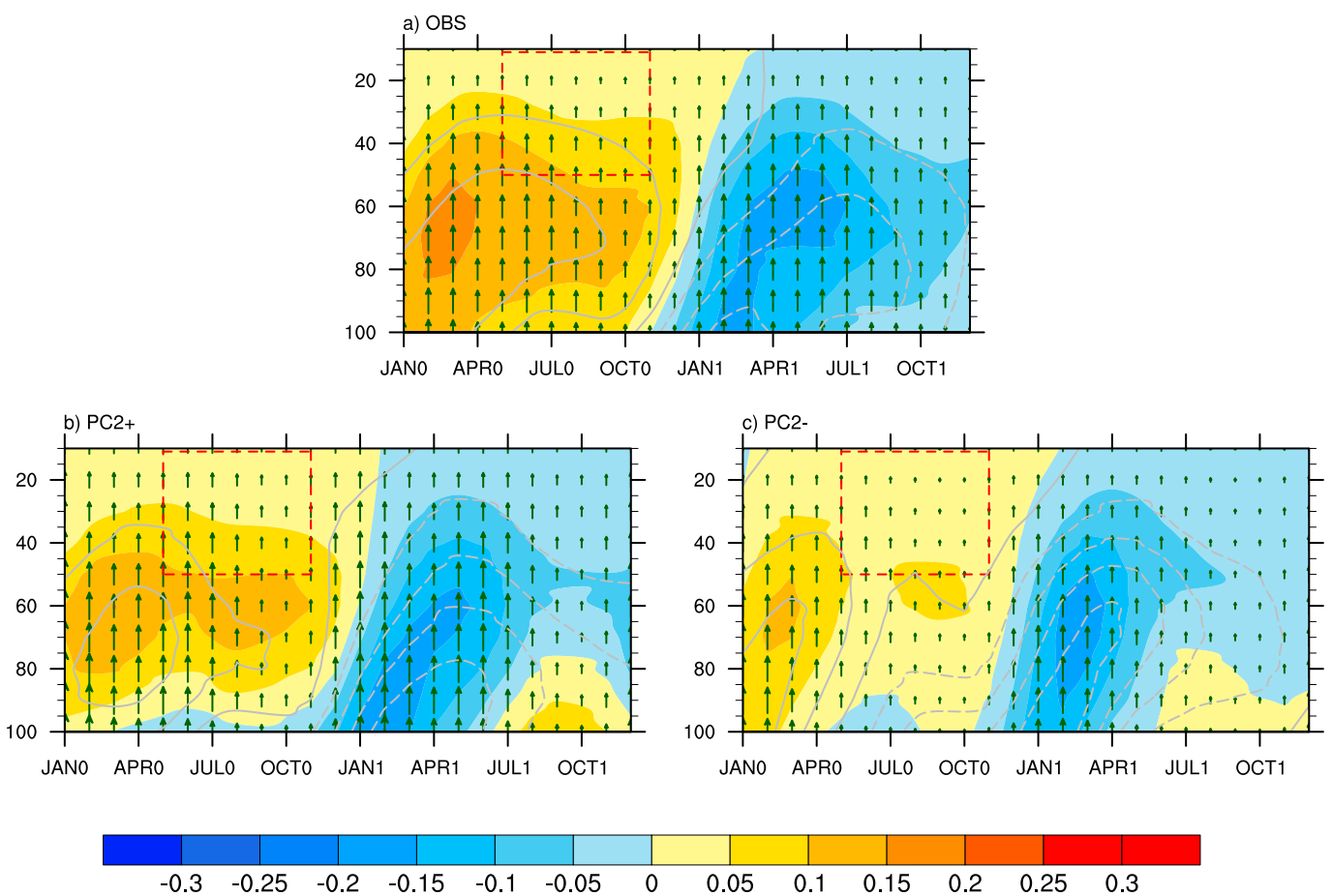

FIG. 13. Composite of anomalous temperature transported by mean vertical currents (shaded; K month ${ }^{-1}$ ), vertical temperature gradient (contours; CI is $86400^{-1} \times 30^{-1} \times 10^{4} \mathrm{~K} \mathrm{~m}^{-1}$, and negative contours are dashed) regressed onto $\mathrm{D}(0) \mathrm{JF}(1)$ Niño-3.4 index, and mean vertical ocean currents (vectors; $10^{-5} \mathrm{~m} \mathrm{~s}^{-1}$ ) averaged over equatorial CEP $\left(5^{\circ} \mathrm{S}-5^{\circ} \mathrm{N}, 170^{\circ}-120^{\circ} \mathrm{W}\right)$ as a function of calendar month and depth for (a) observations, (b) PC2+ models, and (c) PC2- models. Red dashed boxes represent month and depth range for the developing phase.

1999; Merryfield and Boer 2005; Eichler et al. 2006; Meehl et al. 2006; Schott et al. 2008; Wen et al. 2014; Chen et al. 2015; Chen et al. 2017). Associated with weak bias of STCs in PC2 - models, $\bar{v}$ - and $\bar{w}$-related $-\bar{v} \partial T^{\prime} / \partial y$ and $-\bar{w} \partial T^{\prime} / \partial z$ are weak, consequently leading to weaker ENSO intensity than observations and $\mathrm{PC} 2+$ models. Note that the differences of SST, winds, and precipitation are weak in $\mathrm{PC} 2-$ models, as shown in Fig. 14c. Thus, in contrast to the atmospheric origins or air-sea interaction, the STCs' biases might originate from ocean models themselves, such as a poor ocean mixing scheme. More work is needed to investigate this possibility by analyzing the Ocean Model Intercomparison Project simulations.

\section{Summary}

This study has evaluated the biases of NWPAC during ENSO decaying summer and its possible mechanisms involved in 32 CMIP5 models. The main conclusions are summarized as follows.

The first EOF mode of NWPAC biases, explaining $21.3 \%$ of total intermodel variance, exhibits a meridional dipole structure of circulation anomalies, which are almost opposite to observations. There is an anomalous cyclone over the NWP, indicating a weaker NWPAC. The cyclone is a westward Rossby wave response to equatorial WP warming in association with positive rainfall anomalies. Thus, models with colder (warmer) SST anomalies over the equatorial WP would have a better (poorer) performance of NWPAC.

The unrealistic equatorial WP SST anomalies in PC1 + models are affected by $-u^{\prime} \partial \bar{T} / \partial x$ and $-\bar{v} \partial T^{\prime} / \partial y$, and these two terms persist through the decaying phase. PC1 - models also show the stronger positive contribution than observations in these two terms, which are further compensated by the damping processes, as $-w^{\prime} \partial \bar{T} / \partial z,-u^{\prime} \partial T^{\prime} / \partial x$, and $Q^{\prime}{ }_{\text {net }} / \rho C_{P} H$. The weak damping processes in $\mathrm{PC} 1+$ models could favor the development of equatorial WP SST anomalies to some extent.

Further analysis reveals that $-\bar{v} \partial T^{\prime} / \partial y,-w^{\prime} \partial \bar{T} / \partial z$, and $-u^{\prime} \partial T^{\prime} / \partial x$ emphasize the influence of anomalous ocean temperature, and indicate the self-adjustment of equatorial WP SST anomalies. The remaining two terms, $-u^{\prime} \partial \bar{T} / \partial x$ and $Q^{\prime}{ }_{\text {net }} / \rho C_{P} H$, are the key processes, and these two terms depend on the zonal structure of mean ocean temperature and climatology mean SST, 

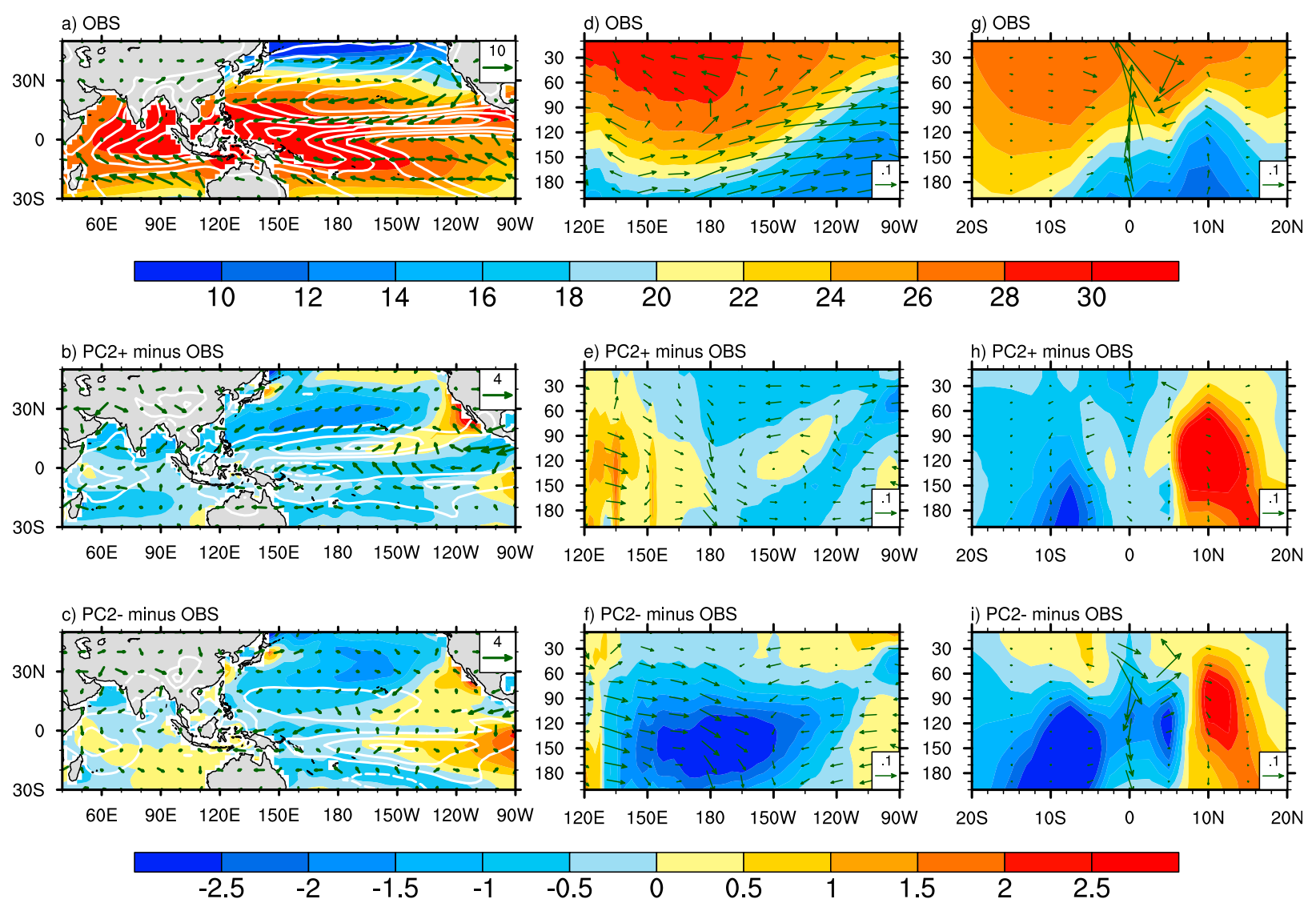

FIG. 14. As in Fig. 10, but for observations, PC2 + models, and PC2 - models. Note that (d)-(f) are along the equator $\left(5^{\circ} \mathrm{S}-5^{\circ} \mathrm{N}\right)$, and (g)-(i) are averaged over the equatorial CEP $\left(170^{\circ}-120^{\circ} \mathrm{W}\right)$.

respectively. The excessive equatorial Pacific cold tongue in $\mathrm{PC} 1+$ models, on the one hand, increases $-\partial \bar{T} / \partial x$, which further intensifies $-u^{\prime} \partial \bar{T} / \partial x$, and favors the development and persistence of equatorial WP SST anomalies. On the other hand, ENSO-related warming is hard to increase convection effectively because of the cold SST biases. Thus, the resulting weakened rainfall response reduces the SWR anomalies, contributing to the SST anomalies there. However, in PC1- models rainfall anomalies are more sensitive to anomalous SST, strengthening the upward SWR anomalies and further $Q^{\prime}{ }_{\text {net }} / \rho C_{P} H$. Thus, the enhancing effect of $-u^{\prime} \partial \bar{T} / \partial x$ is compensated by the damping process, preventing the development of equatorial WP SST anomalies. The detailed mechanism is summarized in Fig. 15.

The second EOF mode of NWPAC biases, explaining $18.6 \%$ of total intermodel variance, exhibits a meridional dipole structure of circulation anomalies and captures an anomalous anticyclone over the NWP, which shifts more northward than observations. The SST anomalies show a tripole pattern over the Indo-Pacific sector, with warming over the equatorial CEP and TIO and cooling over the WP. In addition, the associated rainfall anomalies exhibit a dipole pattern over the tropical Pacific. Thus, models with stronger (weaker) SST anomalies over the equatorial CEP, TIO, and NWP tend to produce a stronger (weaker) anomalous NWPAC shifting more (less) northward.

The TIO and NWP SST anomalies could be largely explained by ENSO-induced atmospheric and oceanic processes, and the differences of SST response there are controlled by different ENSO intensity. $\mathrm{PC} 2+$ and PC2 - models simulate larger and smaller SST anomalies over the equatorial CEP, TIO, and NWP than observations, suggesting the stronger and weaker ENSO intensity, respectively. Therefore, the EOF2 mode reveals that the discrepancy of models simulating ENSO intensity leads to NWPAC biases.

During the developing phase, the discrepancies of $-v^{\prime} \partial \bar{T} / \partial y,-\bar{v} \partial T^{\prime} / \partial y$, and $-\bar{w} \partial T^{\prime} / \partial z$ in observations and models contribute to the different development of equatorial CEP SST anomalies and cause discrepancies in ENSO intensity, as shown in Fig. 15b. The enhancing effect of $-\bar{v} \partial T^{\prime} / \partial y$ could persist into the decaying phase 


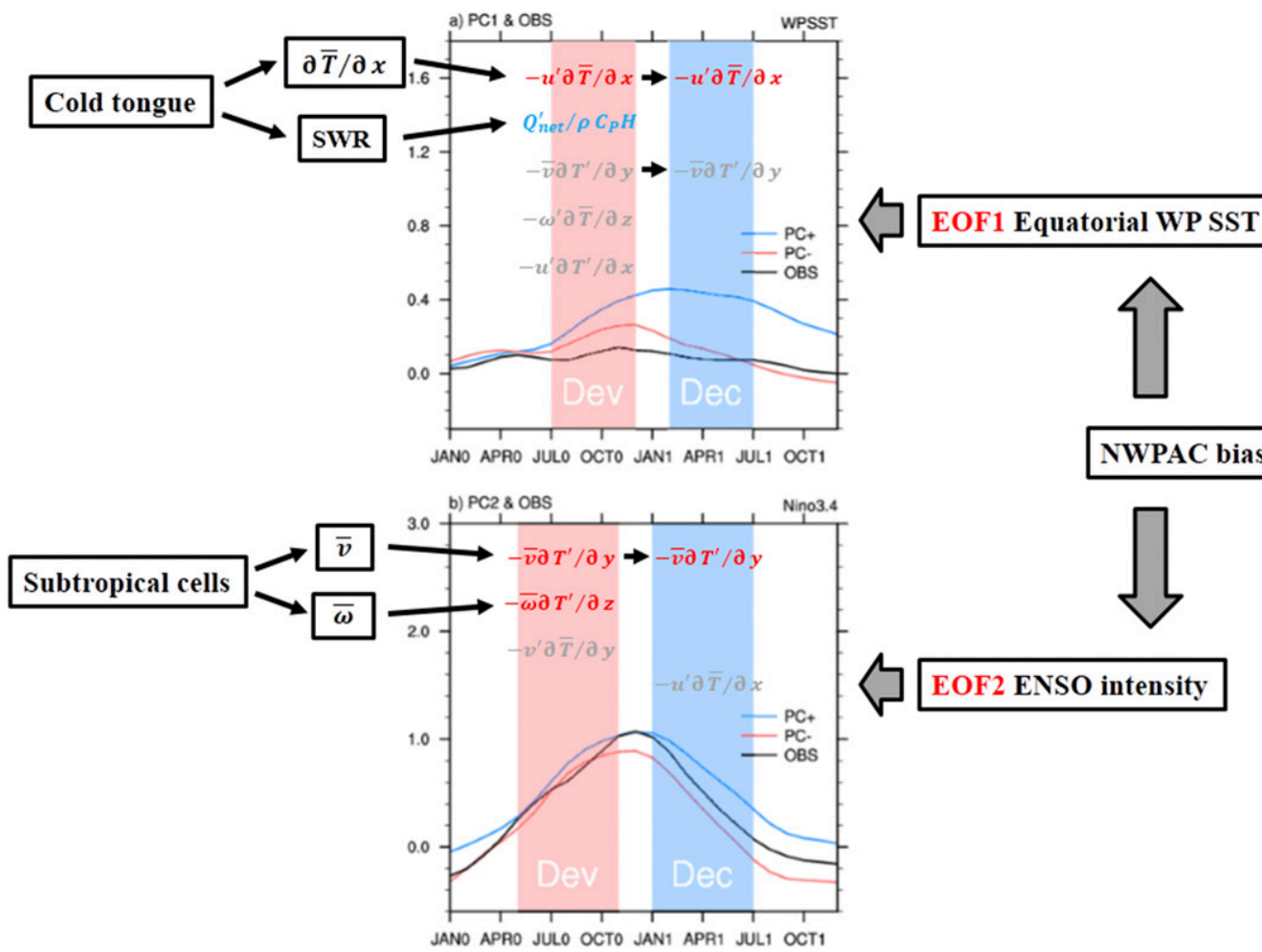

FIG. 15. Schematic diagram illustrates the origins of NWPAC biases for the (a) EOF1 and (b) EOF2 mode. Background is as in Fig. 5. Red and blue terms represent the main enhancing and damping processes, respectively. Gray terms represent the self-adjustment processes. The NWPAC biases in CMIP5 models are caused by biases of ENSO-related SST anomalies, which originate from two parts: One is related to the equatorial WP SST anomalies, and the other depends on ENSO intensity.

and cooperate with $-u^{\prime} \partial \bar{T} / \partial x$ to cause the different ENSO decaying pace. Actually, $-v^{\prime} \partial \bar{T} / \partial y$ and $-u^{\prime} \partial \bar{T} / \partial x$ are controlled by $v^{\prime}$ and $u^{\prime}$, respectively, which are coupled with anomalous ocean temperature, and these two terms reflect the self-adjustment of ENSO. The other two terms, $-\bar{v} \partial T^{\prime} / \partial y$ and $-\bar{w} \partial T^{\prime} / \partial z$ in the developing phase, are more important in causing the discrepancies in ENSO intensity and its evolution feature, and these two terms are determined by $\bar{v}$ and $\bar{w}$, respectively. Associated with weak bias of STCs in PC2- models, $\bar{v}$ - and $\bar{w}$-related $-\bar{v} \partial T^{\prime} / \partial y$ and $-\bar{w} \partial T^{\prime} / \partial z$ are weak, consequently leading to weaker ENSO intensity than in observations and PC2 + models.

Acknowledgments. We acknowledge the World Climate Research Programme's Working Group on Coupled Modelling, which is responsible for CMIP, and we thank the climate modeling groups (listed in Table 1 of this paper) for producing and making available their model output. For CMIP, the U.S. Department of Energy's Program for Climate Model Diagnosis and Intercomparison provides coordinating support and led development of software infrastructure in partnership with the Global Organization for Earth System Science
Portals. We also thank three anonymous reviewers as well as the editor for their useful comments. This work was supported by the China Postdoctoral Science Foundation (2016LH0005 and 2016M600116), the National Natural Science Foundation of China (41705068, 41425019, 41721004, and 41661144016), the Strategic Priority Research Program of Chinese Academy of Sciences (XDA20060501), and the Public Science and Technology Research Funds Projects of Ocean (201505013).

\section{REFERENCES}

Berry, D. I., and E. C. Kent, 2009: A new air-sea interaction gridded dataset from ICOADS with uncertainty estimates. Bull. Amer. Meteor. Soc., 90, 645-656, https://doi.org/10.1175/ 2008BAMS2639.1.

Carton, J. A., and B. S. Giese, 2008: A reanalysis of ocean climate using Simple Ocean Data Assimilation (SODA). Mon. Wea. Rev., 136, 2999-3017, https://doi.org/10.1175/2007MWR1978.1.

$\longrightarrow, \ldots$, and S. A. Grodsky, 2005: Sea level rise and the warming of the oceans in the Simple Ocean Data Assimilation (SODA) ocean reanalysis. J. Geophys. Res., 110, C09006, https://doi.org/ 10.1029/2004JC002817.

Chang, C.-P., Y. Zhang, and T. Li, 2000: Interannual and interdecadal variations of the East Asian summer monsoon and 
tropical Pacific SSTs. Part I: Roles of the subtropical ridge. J. Climate, 13, 4310-4325, https://doi.org/10.1175/ 1520-0442(2000)013<4310:IAIVOT>2.0.CO;2.

Chen, L., T. Li, and Y. Yu, 2015: Causes of strengthening and weakening of ENSO amplitude under global warming in four CMIP5 models. J. Climate, 28, 3250-3274, https://doi.org/ 10.1175/JCLI-D-14-00439.1.

,,,--- and S. K. Behera, 2017: A possible explanation for the divergent projection of ENSO amplitude change under global warming. Climate Dyn., 49, 3799-3811, https://doi.org/ 10.1007/s00382-017-3544-x.

Chen, M., P. Xie, J. E. Janowiak, and P. A. Arkin, 2002: Global land precipitation: A 50-yr monthly analysis based on gauge observations. J. Hydrometeor., 3, 249-266, https://doi.org/ 10.1175/1525-7541(2002)003<0249:GLPAYM > 2.0.CO;2.

Chen, Wei, J.-Y. Lee, K.-J. Ha, K.-S. Yun, and R. Lu, 2016: Intensification of the western North Pacific anticyclone response to the short decaying El Niño event due to greenhouse warming. J. Climate, 29, 3607-3627, https://doi.org/10.1175/ JCLI-D-15-0195.1.

Chen, Wen, H.-F. Graf, and R. Huang, 2000: The interannual variability of East Asian winter monsoon and its relation to the summer monsoon. Adv. Atmos. Sci., 17, 48-60, https://doi.org/ 10.1007/s00376-000-0042-5.

- J. Feng, and R. Wu, 2013: Roles of ENSO and PDO in the link of the East Asian winter monsoon to the following summer monsoon. J. Climate, 26, 622-635, https://doi.org/10.1175/ JCLI-D-12-00021.1.

Chen, Z., Z. Wen, R. Wu, P. Zhao, and J. Cao, 2014: Influence of two types of El Niños on the East Asian climate during boreal summer: A numerical study. Climate Dyn., 43, 469-481, https://doi.org/10.1007/s00382-013-1943-1.

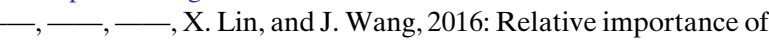
tropical SST anomalies in maintaining the western North Pacific anomalous anticyclone during El Niño to La Niña transition years. Climate Dyn., 46, 1027-1041, https://doi.org/ 10.1007/s00382-015-2630-1.

Chiang, J. C. H., and A. H. Sobel, 2002: Tropical tropospheric temperature variations caused by ENSO and their influence on the remote tropical climate. J. Climate, 15, 2616-2631, https://doi.org/10.1175/1520-0442(2002)015<2616: TTTVCB $>2.0 . \mathrm{CO} ; 2$.

- , and B. R. Lintner, 2005: Mechanisms of remote tropical surface warming during El Niño. J. Climate, 18, 4130-4149, https://doi.org/10.1175/JCLI3529.1.

Chou, C., L.-F. Huang, J.-Y. Tu, L. Tseng, and Y.-C. Hsueh, 2009: El Niño impacts on precipitation in the western North PacificEast Asian sector. J. Climate, 22, 2039-2057, https://doi.org/ 10.1175/2008JCLI2649.1.

Chowdary, J. S., A. Parekh, R. Kakatkar, C. Gnanaseelan, G. Srinivas, P. Singh, and M. K. Roxy, 2016: Tropical Indian Ocean response to the decay phase of El Niño in a coupled model and associated changes in South and East-Asian summer monsoon circulation and rainfall. Climate Dyn., 47, 831844, https://doi.org/10.1007/s00382-015-2874-9.

— , H. S. Harsha, C. Gnanaseelan, G. Srinivas, A. Parekh, P. Pillai, and C. V. Naidu, 2017: Indian summer monsoon rainfall variability in response to differences in the decay phase of El Niño. Climate Dyn., 48, 2707-2727, https://doi.org/ 10.1007/s00382-016-3233-1.

Collins, M., and Coauthors, 2010: The impact of global warming on the tropical Pacific Ocean and El Niño. Nat. Geosci., 3, 391397, https://doi.org/10.1038/ngeo868. de Szoeke, S. P., S.-P. Xie, T. Miyama, K. J. Richards, and R. J. O. Small, 2007: What maintains the SST front north of the eastern Pacific equatorial cold tongue? J. Climate, 20, 2500-2514, https://doi.org/10.1175/JCLI4173.1.

Dong, D., G. Huang, W. Tao, R. Wu, K. Hu, and C. Li, 2018: Interannual variation of precipitation over the Hengduan Mountains during rainy season. Int. J. Climatol., 38, 21122125, https://doi.org/10.1002/joc.5321.

Du, Y., S.-P. Xie, G. Huang, and K. Hu, 2009: Role of air-sea interaction in the long persistence of El Niño-induced north Indian Ocean warming. J. Climate, 22, 2023-2038, https://doi.org/ 10.1175/2008JCLI2590.1.

Eichler, T., D. Rind, and S. Zebiak, 2006: Impact of global warming on ENSO variability using the coupled GISS GCM/ ZC model. Int. J. Climatol., 26, 1283-1314, https://doi.org/ 10.1002/joc. 1308 .

Feng, J., L. Wang, and W. Chen, 2014: How does the East Asian summer monsoon behave in the decaying phase of El Niño during different PDO phases? J. Climate, 27, 2682-2698, https://doi.org/10.1175/JCLI-D-13-00015.1.

Fu, Y., and R. Lu, 2017: Improvements in simulating the relationship between ENSO and East Asian summer rainfall in the CMIP5 models. J. Climate, 30, 4513-4525, https://doi.org/ 10.1175/JCLI-D-16-0606.1.

, — , H. Wang, and X. Yang, 2013: Impact of overestimated ENSO variability in the relationship between ENSO and East Asian summer rainfall. J. Geophys. Res. Atmos., 118, 62006211, https://doi.org/10.1002/jgrd.50482.

Gong, H., L. Wang, W. Chen, D. Nath, G. Huang, and W. Tao, 2015: Diverse influences of ENSO on the East Asian-western Pacific winter climate tied to different ENSO properties in CMIP5 models. J. Climate, 28, 2187-2202, https://doi.org/ 10.1175/JCLI-D-14-00405.1.

Guilyardi, E., 2006: El Niño-mean state-seasonal cycle interactions in a multi-model ensemble. Climate Dyn., 26, 329348, https://doi.org/10.1007/s00382-005-0084-6.

Ham, Y.-G., and J.-S. Kug, 2015: Improvement of ENSO simulation based on intermodel diversity. J. Climate, 28, 998-1015, https://doi.org/10.1175/JCLI-D-14-00376.1.

He, C., and T. Zhou, 2014: The two interannual variability modes of the western North Pacific subtropical high simulated by 28 CMIP5-AMIP models. Climate Dyn., 43, 2455-2469, https:// doi.org/10.1007/s00382-014-2068-x.

$\longrightarrow$, and -2015 : Responses of the western North Pacific subtropical high to global warming under RCP4.5 and RCP8.5 scenarios projected by 33 CMIP5 models: The dominance of tropical Indian Ocean-tropical western Pacific SST gradient. J. Climate, 28, 365-380, https://doi.org/10.1175/JCLI-D-13-00494.1.

,-- A. Lin, B. Wu, D. Gu, C. Li, and B. Zheng, 2015: Enhanced or weakened western North Pacific subtropical high under global warming? Sci. Rep., 5, 16771, https://doi.org/ 10.1038/srep16771.

Hirota, N., Y. N. Takayabu, M. Watanabe, and M. Kimoto, 2011: Precipitation reproducibility over tropical oceans and its relationship to the double ITCZ problem in CMIP3 and MIROC5 climate models. J. Climate, 24, 4859-4873, https:// doi.org/10.1175/2011JCLI4156.1.

Hu, K., G. Huang, and R. Huang, 2011: The impact of tropical Indian Ocean variability on summer surface air temperature in China. J. Climate, 24, 5365-5377, https://doi.org/10.1175/ 2011JCLI4152.1.

- — - X. Qu, and R. Huang, 2012: The impact of Indian Ocean variability on high temperature extremes across the 
southern Yangtze River valley in late summer. Adv. Atmos. Sci., 29, 91-100, https://doi.org/10.1007/s00376-011-0209-2.

, — - X.-T. Zheng, S.-P. Xie, X. Qu, Y. Du, and L. Liu, 2014: Interdecadal variations in ENSO influences on northwest Pacific-East Asian early summertime climate simulated in CMIP5 models. J. Climate, 27, 5982-5998, https://doi.org/ 10.1175/JCLI-D-13-00268.1.

— Niño effect on summer rainfall in central China. J. Climate, $\mathbf{3 0}$, 10 037-10 045, https://doi.org/10.1175/JCLI-D-17-0312.1.

Hu, W., and R. Wu, 2015: Relationship between South China Sea precipitation variability and tropical Indo-Pacific SST anomalies in IPCC CMIP5 models during spring-to-summer transition. Adv. Atmos. Sci., 32, 1303-1318, https://doi.org/10.1007/ s00376-015-4250-4.

Hu, Z.-Z., A. Kumar, Y. Xue, and B. Jha, 2014: Why were some La Niñas followed by another La Niña? Climate Dyn., 42, 10291042, https://doi.org/10.1007/s00382-013-1917-3.

Huang, P., P. Wang, K. Hu, G. Huang, Z. Zhang, Y. Liu, and B. Yan, 2014: An introduction to the integrated climate model of the Center for Monsoon System Research and its simulated influence of El Niño on East Asian-western North Pacific climate. Adv. Atmos. Sci., 31, 1136-1146, https://doi.org/ 10.1007/s00376-014-3233-1.

Huang, R., J. Chen, L. Wang, and Z. Lin, 2012: Characteristics, processes, and causes of the spatio-temporal variabilities of the East Asian monsoon system. Adv. Atmos. Sci., 29, 910942, https://doi.org/10.1007/s00376-012-2015-x.

Hwang, Y.-T., and D. M. W. Frierson, 2013: Link between the double-intertropical convergence zone problem and cloud biases over the Southern Ocean. Proc. Natl. Acad. Sci. USA, 110, 4935-4940, https://doi.org/10.1073/pnas.1213302110.

Inoue, T., and H. Ueda, 2009: Evaluation for the seasonal evolution of the summer monsoon over the Asian and western North Pacific sector in the WCRP CMIP3 multi-model experiments. J. Meteor. Soc. Japan, 87, 539-560, https://doi.org/10.2151/ jmsj.87.539.

Jiang, W., G. Huang, K. Hu, R. Wu, H. Gong, X. Chen, and W. Tao, 2017: Diverse relationship between ENSO and the northwest Pacific summer climate among CMIP5 models: Dependence on the ENSO decay pace. J. Climate, 30, 109-127, https://doi.org/ 10.1175/JCLI-D-16-0365.1.

Jin, E. K., and Coauthors, 2008: Current status of ENSO prediction skill in coupled ocean-atmosphere models. Climate Dyn., $\mathbf{3 1}$, 647-664, https://doi.org/10.1007/s00382-008-0397-3.

Kalnay, E., and Coauthors, 1996: The NCEP/NCAR 40-Year Reanalysis Project. Bull. Amer. Meteor. Soc., 77, 437-471, https:// doi.org/10.1175/1520-0477(1996)077<0437:TNYRP>2.0.CO;2.

Karori, M. A., J. Li, and F.-F. Jin, 2013: The asymmetric influence of the two types of El Niño and La Niña on summer rainfall over southeast China. J. Climate, 26, 4567-4582, https://doi.org/ 10.1175/JCLI-D-12-00324.1.

Kessler, W. S., 2002: Is ENSO a cycle or a series of events? Geophys. Res. Lett., 29, 2125, https://doi.org/10.1029/2002GL015924.

Kim, S. T., and J.-Y. Yu, 2012: The two types of ENSO in CMIP5 models. Geophys. Res. Lett., 39, L11704, https://doi.org/ 10.1029/2012GL052006.

_, W. Cai, F.-F. Jin, and J.-Y. Yu, 2014: ENSO stability in coupled climate models and its association with mean state. Climate Dyn., 42, 3313-3321, https://doi.org/10.1007/s00382-013-1833-6.

Kleeman, R., J. P. McCreary Jr., and B. A. Klinger, 1999: A mechanism for generating ENSO decadal variability. Geophys. Res. Lett., 26, 1743-1746, https://doi.org/10.1029/1999GL900352.
Klein, S. A., B. J. Soden, and N.-C. Lau, 1999: Remote sea surface temperature variations during ENSO: Evidence for a tropical atmospheric bridge. J. Climate, 12, 917-932, https://doi.org/ 10.1175/1520-0442(1999)012<0917:RSSTVD>2.0.CO;2.

Kosaka, Y., and H. Nakamura, 2011: Dominant mode of climate variability, intermodel diversity, and projected future changes over the summertime western North Pacific simulated in the CMIP3 models. J. Climate, 24, 3935-3955, https://doi.org/ 10.1175/2011JCLI3907.1.

—, S.-P. Xie, N.-C. Lau, and G. A. Vecchi, 2013: Origin of seasonal predictability for summer climate over the northwestern Pacific. Proc. Natl. Acad. Sci. USA, 110, 7574-7579, https://doi. org/10.1073/pnas.1215582110.

Larkin, N. K., and D. E. Harrison, 2002: ENSO warm (El Niño) and cold (La Niña) event life cycles: Ocean surface anomaly patterns, their symmetries, asymmetries, and implications. J. Climate, 15, 1118-1140, https://doi.org/10.1175/1520-0442(2002)015<1118: EWENOA $>2.0 . \mathrm{CO} ; 2$.

Lau, N.-C., and M. J. Nath, 2003: Atmosphere-ocean variations in the Indo-Pacific sector during ENSO episodes. J. Climate, 16, 3-20, https://doi.org/10.1175/1520-0442(2003)016<0003: AOVITI $>2.0 . \mathrm{CO} ; 2$.

Lee, S.-K., P. N. DiNezio, E.-S. Chung, S.-W. Yeh, A. T. Wittenberg, and C. Wang, 2014: Spring persistence, transition, and resurgence of El Niño. Geophys. Res. Lett., 41, 8578-8585, https://doi.org/10.1002/2014GL062484.

Li, C., 1990: Interaction between anomalous winter monsoon in East Asia and El Niño events. Adv. Atmos. Sci., 7, 36-46, https://doi.org/10.1007/BF02919166.

Li, G., and S.-P. Xie, 2014: Tropical biases in CMIP5 multimodel ensemble: The excessive equatorial Pacific cold tongue and double ITCZ problems. J. Climate, 27, 1765-1780, https://doi. org/10.1175/JCLI-D-13-00337.1.

— Y. Yu, H. Xu, and B. Ren, 2015: An intermodel approach to identify the source of excessive equatorial Pacific cold tongue in CMIP5 models and uncertainty in observational datasets. J. Climate, 28, 7630-7640, https://doi.org/10.1175/JCLI-D-15-0168.1.

Lin, J.-L., 2007: The double-ITCZ problem in IPCC AR4 coupled GCMs: Ocean-atmosphere feedback analysis. J. Climate, 20, 4497-4525, https://doi.org/10.1175/JCLI4272.1.

Liu, B., G. Huang, K. Hu, R. Wu, H. Gong, P. Wang, and G. Zhao, 2018: The multidecadal variations of the interannual relationship between the East Asian summer monsoon and ENSO in a coupled model. Climate Dyn., https://doi.org/ 10.1007/s00382-017-3976-3, in press.

Luo, J.-J., S. Masson, E. Roeckner, G. Madec, and T. Yamagata, 2005: Reducing climatology bias in an ocean-atmosphere CGCM with improved coupling physics. J. Climate, 18, 2344-2360, https://doi.org/10.1175/JCLI3404.1.

Magnusson, L., M. Alonso-Balmaseda, and F. Molteni, 2013: On the dependence of ENSO simulation on the coupled model mean state. Climate Dyn., 41, 1509-1525, https://doi.org/ 10.1007/s00382-012-1574-y.

McCreary, J. P., Jr., and P. Lu, 1994: Interaction between the subtropical and equatorial ocean circulations: The subtropical cell. J. Phys. Oceanogr., 24, 466-497, https://doi.org/10.1175/ 1520-0485(1994)024<0466:IBTSAE > 2.0.CO;2.

McPhaden, M. J., and X. Zhang, 2009: Asymmetry in zonal phase propagation of ENSO sea surface temperature anomalies. Geophys. Res. Lett., 36, L13703, https://doi.org/ 10.1029/2009GL038774.

Mechoso, C. R., and Coauthors, 1995: The seasonal cycle over the tropical Pacific in coupled ocean-atmosphere general 
circulation models. Mon. Wea. Rev., 123, 2825-2838, https:// doi.org/10.1175/1520-0493(1995)123<2825:TSCOTT>2.0.CO;2.

Meehl, G. A., H. Teng, and G. Branstator, 2006: Future changes of El Niño in two global coupled climate models. Climate Dyn., 26, 549-566, https://doi.org/10.1007/s00382-005-0098-0.

—, C. Covey, T. Delworth, M. Latif, B. McAvaney, J. F. B. Mitchell, R. J. Stouffer, and K. E. Taylor, 2007: The WCRP CMIP3 multimodel dataset: A new era in climate change research. Bull. Amer. Meteor. Soc., 88, 1383-1394, https://doi. org/10.1175/BAMS-88-9-1383.

Merryfield, W. J., and G. J. Boer, 2005: Variability of upper Pacific Ocean overturning in a coupled climate model. J. Climate, $\mathbf{1 8}$, 666-683, https://doi.org/10.1175/JCLI-3282.1.

Neelin, J. D., and Coauthors, 1992: Tropical air-sea interaction in general circulation models. Climate Dyn., 7, 73-104, https:// doi.org/10.1007/BF00209610.

North, G. R., T. L. Bell, R. F. Cahalan, and F. J. Moeng, 1982: Sampling errors in the estimation of empirical orthogonal functions. Mon. Wea. Rev., 110, 699-706, https://doi.org/ 10.1175/1520-0493(1982)110<0699:SEITEO > 2.0.CO;2.

Qu, X., 2017: The intermodel diversity of East Asia's summer rainfall among CMIP5 models. J. Climate, 30, 9287-9301, https://doi.org/10.1175/JCLI-D-17-0094.1.

Ramanathan, V., and W. Collins, 1991: Thermodynamic regulation of ocean warming by cirrus clouds deduced from observations of the 1987 El Niño. Nature, 351, 27-32, https://doi.org/ $10.1038 / 351027 \mathrm{a} 0$.

Rayner, N. A., D. E. Parker, E. B. Horton, C. K. Folland, L. V. Alexander, D. P. Rowell, E. C. Kent, and A. Kaplan, 2003: Global analyses of sea surface temperature, sea ice, and night marine air temperature since the late nineteenth century. J. Geophys. Res., 108, 4407, https://doi.org/10.1029/2002JD002670.

Schott, F. A., L. Stramma, W. Wang, B. S. Giese, and R. Zantopp, 2008: Pacific subtropical cell variability in the SODA 2.0.2/3 assimilation. Geophys. Res. Lett., 35, L10607, https://doi.org/ 10.1029/2008GL033757.

Song, F., and T. Zhou, 2014: The climatology and interannual variability of East Asian summer monsoon in CMIP5 coupled models: Does air-sea coupling improve the simulations? J. Climate, 27, 8761-8777, https://doi.org/10.1175/JCLI-D-14-00396.1.

Spencer, H., R. Sutton, and J. M. Slingo, 2007: El Niño in a coupled climate model: Sensitivity to changes in mean state induced by heat flux and wind stress corrections. J. Climate, 20, 2273-2298, https://doi.org/10.1175/JCLI4111.1.

Stuecker, M. F., A. Timmermann, F.-F. Jin, S. McGregor, and H.- L. Ren, 2013: A combination mode of the annual cycle and the El Niño/Southern Oscillation. Nat. Geosci., 6, 540-544, https://doi.org/10.1038/ngeo1826.

— , F.-F. Jin, A. Timmermann, and S. McGregor, 2015: Combination mode dynamics of the anomalous northwest Pacific anticyclone. J. Climate, 28, 1093-1111, https://doi.org/10.1175/ JCLI-D-14-00225.1.

Su, H., J. D. Neelin, and J. E. Meyerson, 2003: Sensitivity of tropical tropospheric temperature to sea surface temperature forcing. J. Climate, 16, 1283-1301, https://doi.org/10.1175/ 1520-0442-16.9.1283.

Tao, W., G. Huang, K. Hu, X. Qu, G. Wen, and Y. Gong, 2014: Different influences of two types of El Niños on the Indian Ocean SST variations. Theor. Appl. Climatol., 117, 475-484, https://doi.org/10.1007/s00704-013-1022-x.

$-,-\longrightarrow,-,-$, and H. Gong, 2015: Interdecadal modulation of ENSO teleconnections to the Indian Ocean Basin mode and their relationship under global warming in
CMIP5 models. Int. J. Climatol., 35, 391-407, https://doi.org/ 10.1002/joc.3987.

,,,--- H. Gong, G. Wen, and L. Liu, 2016: A study of biases in simulation of the Indian Ocean Basin mode and its capacitor effect in CMIP3/CMIP5 models. Climate Dyn., 46, 205-226, https://doi.org/10.1007/s00382-015-2579-0.

$-,-, \mathrm{R} . \mathrm{Wu}, \mathrm{K} . \mathrm{Hu}, \mathrm{P}$. Wang, and D. Chen, 2017: Asymmetry in summertime atmospheric circulation anomalies over the northwest Pacific during decaying phase of El Niño and La Niña. Climate Dyn., 49, 2007-2023, https://doi.org/10.1007/ s00382-016-3432-9.

Taylor, K. E., R. J. Stouffer, and G. A. Meehl, 2012: An overview of CMIP5 and the experiment design. Bull. Amer. Meteor. Soc., 93, 485-498, https://doi.org/10.1175/BAMS-D-11-00094.1.

Uppala, S. M., and Coauthors, 2005: The ERA-40 Re-Analysis. Quart. J. Roy. Meteor. Soc., 131, 2961-3012, https://doi.org/ 10.1256/qj.04.176.

Wang, B., 1992: The vertical structure and development of the ENSO anomaly mode during 1979-1989. J. Atmos. Sci., 49, 698-712, https://doi.org/10.1175/1520-0469(1992)049<0698: TVSADO $>2.0 . \mathrm{CO} ; 2$.

_- and Q. Zhang, 2002: Pacific-East Asian teleconnection. Part II: How the Philippine Sea anomalous anticyclone is established during El Niño development. J. Climate, 15, 3252-3265, https://doi.org/10.1175/1520-0442(2002)015<3252: PEATPI $>2.0 . \mathrm{CO} ; 2$.

$\longrightarrow, \mathrm{R} . \mathrm{Wu}$, and X. Fu, 2000: Pacific-East Asian teleconnection: How does ENSO affect East Asian climate? J. Climate, 13 1517-1536, https://doi.org/10.1175/1520-0442(2000)013<1517: PEATHD $>2.0 . \mathrm{CO} ; 2$.

— Z. Wu, J. Li, J. Liu, C.-P. Chang, Y. Ding, and G. Wu, 2008: How to measure the strength of the East Asian summer monsoon. J. Climate, 21, 4449-4463, https://doi.org/10.1175/ 2008JCLI2183.1.

_ B. Biang, and J.-Y. Lee, 2013: Subtropical high predictability establishes a promising way for monsoon and tropical storm predictions. Proc. Natl. Acad. Sci. USA, 110, 2718-2722, https://doi.org/10.1073/pnas.1214626110.

Wang, L., and R. Wu, 2012: In-phase transition from the winter monsoon to the summer monsoon over East Asia: Role of the Indian Ocean. J. Geophys. Res., 117, D11112, https://doi.org/ 10.1029/2012JD017509.

— , and W. Chen, 2014: An intensity index for the East Asian winter monsoon. J. Climate, 27, 2361-2374, https://doi.org/ 10.1175/JCLI-D-13-00086.1.

Watanabe, M., and F.-F. Jin, 2002: Role of Indian Ocean warming in the development of Philippine Sea anticyclone during ENSO. Geophys. Res. Lett., 29, 1478, https://doi.org/10.1029/ 2001 GL014318.

Wen, C., A. Kumar, Y. Xue, and M. J. McPhaden, 2014: Changes in tropical Pacific thermocline depth and their relationship to ENSO after 1999. J. Climate, 27, 7230-7249, https://doi.org/ 10.1175/JCLI-D-13-00518.1.

Wu, B., T. Zhou, and T. Li, 2009: Seasonally evolving dominant interannual variability modes of East Asian climate. J. Climate, 22, 2992-3005, https://doi.org/10.1175/2008JCLI2710.1.

— , T. Li, and T. Zhou, 2010a: Asymmetry of atmospheric circulation anomalies over the western North Pacific between El Niño and La Niña. J. Climate, 23, 4807-4822, https://doi.org/ 10.1175/2010JCLI3222.1.

,-- , and $-2010 \mathrm{~b}$ : Relative contributions of the Indian Ocean and local SST anomalies to the maintenance of the western North Pacific anomalous anticyclone during the 
El Niño decaying summer. J. Climate, 23, 2974-2986, https:// doi.org/10.1175/2010JCLI3300.1.

Wu, R., and S.-W. Yeh, 2010: A further study of the tropical Indian Ocean asymmetric mode in boreal spring. J. Geophys. Res., 115, D08101, https://doi.org/10.1029/2009JD012999.

— Z.Z. Hu, and B. P. Kirtman, 2003: Evolution of ENSOrelated rainfall anomalies in East Asia. J. Climate, 16, 3742-3758, https://doi.org/10.1175/1520-0442(2003)016<3742: EOERAI $>2.0 . \mathrm{CO} ; 2$.

- G. Huang, Z. Du, and K. Hu, 2014a: Cross-season relation of the South China Sea precipitation variability between winter and summer. Climate Dyn., 43, 193-207, https://doi.org/ 10.1007/s00382-013-1820-y.

_ , W. Chen, G. Wang, and K. Hu, 2014b: Relative contribution of ENSO and East Asian winter monsoon to the South China Sea SST anomalies during ENSO decaying years. J. Geophys. Res. Atmos., 119, 5046-5064, https://doi.org/ 10.1002/2013jd021095.

Xie, S.-P., and Z.-Q. Zhou, 2017: Seasonal modulations of El Niñorelated atmospheric variability: Indo-western Pacific Ocean feedback. J. Climate, 30, 3461-6472, https://doi.org/10.1175/ JCLI-D-16-0713.1.

—, H. Annamalai, F. A. Schott, and J. P. McCreary Jr., 2002: Structure and mechanisms of south Indian Ocean climate variability. J. Climate, 15, 864-878, https://doi.org/10.1175/ 1520-0442(2002)015<0864:SAMOSI > 2.0.CO;2.

-, K. Hu, J. Hafner, H. Tokinaga, Y. Du, G. Huang, and T. Sampe, 2009: Indian Ocean capacitor effect on Indowestern Pacific climate during the summer following El Niño. J. Climate, 22, 730-747, https://doi.org/10.1175/ 2008JCLI2544.1.

_ , Y. Kosaka, Y. Du, K. Hu, J. S. Chowdary, and G. Huang, 2016: Indo-western Pacific Ocean capacitor and coherent climate anomalies in post-ENSO summer: A review. Adv. Atmos. Sci., 33, 411-432, https://doi.org/10.1007/s00376-015-5192-6.

Yang, J., Q. Liu, S.-P. Xie, Z. Liu, and L. Wu, 2007: Impact of the Indian Ocean SST basin mode on the Asian summer monsoon. Geophys. Res. Lett., 34, L02708, https://doi.org/10.1029/ 2006 GL028571.

, and Z. Liu, 2010: Linking observations of the Asian monsoon to the Indian Ocean SST: Possible roles of Indian Ocean Basin mode and dipole mode. J. Climate, 23, 58895902, https://doi.org/10.1175/2010JCLI2962.1.
Yu, J.-Y., and C. R. Mechoso, 1999: Links between annual variations of Peruvian stratocumulus clouds and of SST in the eastern equatorial Pacific. J. Climate, 12, 3305-3318, https://doi.org/ 10.1175/1520-0442(1999)012<3305:LBAVOP $>2.0$. CO 2.

Yu, L., and R. A. Weller, 2007: Objectively analyzed air-sea heat fluxes for the global ice-free oceans (1981-2005). Bull. Amer. Meteor. Soc., 88, 527-539, https://doi.org/10.1175/BAMS-88-4-527.

Yun, K.-S., S.-W. Yeh, and K.-J. Ha, 2015: Covariability of western tropical Pacific-North Pacific atmospheric circulation during summer. Sci. Rep., 5, 16980, https://doi.org/10.1038/srep16980.

Zhang, G. J., and H. Wang, 2006: Toward mitigating the double ITCZ problem in NCAR CCSM3. Geophys. Res. Lett., 33, L06709, https://doi.org/10.1029/2005GL025229.

Zhang, R., and A. Sumi, 2002: Moisture circulation over East Asia during El Niño episode in northern winter, spring and autumn. J. Meteor. Soc. Japan, 80, 213-227, https://doi.org/10.2151/ jmsj.80.213.

,-- , and M. Kimoto, 1996: Impact of El Niño on the East Asian monsoon: A diagnostic study of the '86/87 and '91/92 events. J. Meteor. Soc. Japan, 74, 49-62, https://doi.org/ 10.2151/jmsj1965.74.1_49.

— T. Li, M. Wen, and L. Liu, 2015: Role of intraseasonal oscillation in asymmetric impacts of El Niño and La Niña on the rainfall over southern China in boreal winter. Climate Dyn., 45, 559-567, https://doi.org/10.1007/s00382-014-2207-4.

Zhang, T., and D.-Z. Sun, 2014: ENSO asymmetry in CMIP5 models. J. Climate, 27, 4070-4093, https://doi.org/10.1175/ JCLI-D-13-00454.1.

Zhang, W., H. Li, M. F. Stuecker, F.-F. Jin, and A. G. Turner, 2016: A new understanding of El Niño's impact over East Asia: Dominance of the ENSO combination mode. J. Climate, 29, 4347-4359, https://doi.org/10.1175/JCLI-D-15-0104.1.

Zhao, G., G. Huang, R. Wu, W. Tao, H. Gong, X. Qu, and K. Hu, 2015: A new upper-level circulation index for the East Asian summer monsoon variability. J. Climate, 28, 9977-9996, https://doi.org/10.1175/JCLI-D-15-0272.1.

Zheng, X.-T., S.-P. Xie, and Q. Liu, 2011: Response of the Indian Ocean Basin mode and its capacitor effect to global warming. J. Climate, 24, 6146-6164, https://doi.org/10.1175/2011JCLI4169.1.

Zheng, Y., J.-L. Lin, and T. Shinoda, 2012: The equatorial Pacific cold tongue simulated by IPCC AR4 coupled GCMs: Upper ocean heat budget and feedback analysis. J. Geophys. Res., 117, C05024, https://doi.org/10.1029/2011JC007746. 